\title{
Abdominal Bloating: Pathophysiology and Treatment
}

\author{
A Young Seo, ${ }^{1}$ Nayoung Kim ${ }^{1,2 *}$ and Dong Hyun $\mathrm{Oh}^{1}$ \\ ${ }^{1}$ Department of Internal Medicine, Seoul National University, Bundang Hospital, Seongnam, Gyeonggi-do, Korea; and ${ }^{2}$ Department of Internal \\ Medicine and Liver Research Institute, Seoul National University College of Medicine, Seoul, Korea
}

\begin{abstract}
Abdominal bloating is a very common and troublesome symptom of all ages, but it has not been fully understood to date. Bloating is usually associated with functional gastrointestinal disorders or organic diseases, but it may also appear alone. The pathophysiology of bloating remains ambiguous, although some evidences support the potential mechanisms, including gut hypersensitivity, impaired gas handling, altered gut microbiota, and abnormal abdominal-phrenic reflexes. Owing to the insufficient understanding of these mechanisms, the available therapeutic options are limited. However, medical treatment with some prokinetics, rifaximin, lubiprostone and linaclotide could be considered in the treatment of bloating. In addition, dietary intervention is important in relieving symptom in patients with bloating.

(J Neurogastroenterol Motil 2013;19:433-453)
\end{abstract}

\section{Key Words}

Bloating; Pathophysiology; Rifaximin; Therapy

\section{Introduction}

Bloating is one of the most common gastrointestinal (GI) symptoms, which is a frequent complaint in the patients of all ages. This symptom is very common in patients with irritable bowel syndrome (IBS) and other functional gastrointestinal disorders (FGIDs) as well as in patients with organic disorders. Many clinicians encounter the patients' complaints such as "too much gas in abdomen," "heavy and uncomfortable feeling in abdomen" and "full belly." The severity of bloating is varied from mild discomfort to severe, and it is one of the bothersome symptoms of the patients, affecting their quality of life. Despite being one of the frequent and bothersome complaints, bloating remains incompletely understood of all the symptoms. Therefore clinicians need to be more considerate when evaluating patients with abdominal bloating.

The possible causes of bloating are various and complicated, thus intestinal gas production and transit, gut microflora and hypersensitivity of the patient's gut might be the factors for the symptom generation. As the underlying mechanism of bloating remains elusive to date, there are few evidences for diagnostic and

Received: September 3, 2013 Revised: September 10, 2013 Accepted: September 16, 2013

(c) This is an Open Access article distributed under the terms of the Creative Commons Attribution Non-Commercial License (http://creativecommons. org/licenses/by-nc/3.0) which permits unrestricted non-commercial use, distribution, and reproduction in any medium, provided the original work is properly cited.

*Correspondence: Nayoung Kim, MD

Department of Internal Medicine, Seoul National University Bundang Hospital, 82 Gumi-ro, 173 Beon-gil, Bundang-gu, Seongnam, Gyeonggi-do 463-707, Korea

Tel: +82-31-787-7008, Fax: +82-31-787-4051, E-mail: nayoungkim49@empas.com

Financial support: This work was supported by the National Research Foundation of Korea (NRF) grant (No. 2011-0030001) for the Global Core Research Center (GCRC) funded by the Korea government (MSIP).

Conflicts of interest: None.

Author contributions: A Young Seo analyzed the references and wrote a manuscript. Dong Hyun Oh collected references and adapted the figures. Nayoung Kim provided ideas, designed and supervised the manuscript. 
therapeutic options available. In addition, patients who complain of bloating tend to have IBS or functional dyspepsia (FD), thus most of the therapeutic approaches of abdominal bloating are based on the treatments of IBS and FD. ${ }^{1-4}$ However bloating could occur alone without associated diseases and there has been not enough data of randomized controlled trials for treatment of bloating alone. The treatments for bloating have not been standardized and there is no evidence-based algorithm. Although there have been several comprehensive reviews for pathophysiology or treatment of abdominal bloating in FGID (Table 1), ${ }^{5-10}$ both clinical trials and systematic reviews regarding functional bloating (FB) alone are scarce so far. Only one available pilot study was from Spain, which indicated that sugar intolerance was frequently observed in patients with $\mathrm{FB}$ and associated with bloating symptom. Additionally, a malabsorbed sugar-free diet gave rise to clinical improvement in high percentage of patients. ${ }^{11}$ Thus, in the clinical setting, rational treatment for bloating is hard and the result of treatment is frequently unsatisfactory. Most treatment options for bloating are similar to treatments for IBS, but as previously mentioned, FB and IBS are in different disease entities.

\section{Aims and Methods}

Our aim was to explain the clinical importance, pathophysiologic mechanisms, and management of abdominal bloating, thus to provide a better understanding of this specific problem. We reviewed the literature of mechanisms and treatment interventions for abdominal bloating based on a PubMed search on the following terms; "abdominal bloating," "intestinal gas and IBS," "distension and IBS" and "FGID." We also quoted important knowledge from a standard textbook, the chapter "intestinal gas." 12

\section{Definition}

Bloating is defined as subjective discomfort by patient's sensation of intestinal gas; otherwise, abdominal distension is a visible increase in abdominal girth. In the past, bloating had been considered to be related to abdominal distension directly, but recent studies have suggested that it is not always accompanied by abdominal distension. ${ }^{13}$ There have been many studies to evaluate the relationship between bloating and abdominal distension. One study has shown that actual abdominal distension only occurred in about half of the patients suffering from bloating. ${ }^{14}$ In addition, some patients with both visceral hypersensitivity and FGID complained of bloating in the absence of visible distension. ${ }^{15,16}$ Briefly, abdominal bloating is the subjective symptom and distension is the objective sign, so bloating and distension should be considered as separate disorders with different mechanisms. Although bloating has been considered as a supportive symptom for IBS or FD according to Rome classification, FB is also included as an independent entity in Rome criteria. ${ }^{17-19}$ The diagnosis of $\mathrm{FB}$ is made in patients who do not meet the diagnostic criteria of IBS or other FGIDs, but have recurrent symptoms of bloating. According to Rome III, the diagnostic criteria include recurrent feeling of bloating or visible distension at least 3 days a month in the last 3 months with symptom onset at least 6 months prior to diagnosis. Also it should exclude FD, IBS or other FGIDs. The name has been changed from functional abdominal bloating in Rome I and II criteria to functional bloating in Rome III criteria. $^{17-19}$

\section{Epidemiology}

'Bloating' has been first described by Alvarez of the Mayo Clinic in 1949, in a woman patient with psychological problem. ${ }^{20}$ In USA, 15-30\% of general population has been reported to experience bloating. ${ }^{16,21,22}$ Also in Asia, similar result has been shown (15-23\%), suggesting that the prevalence of bloating is not interracially different. ${ }^{23}$ Though the data for FB alone are relatively little, women typically have higher rates of bloating than men according to the reports of IBS. ${ }^{16,21,22}$ This relevance between female gender and bloating has long been suggested and the hormonal effect in connection with menstrual cycle is regarded as one of the possible explanation. ${ }^{24,25}$ Besides, there are some reports of obese people experiencing more GI symptoms such as abdominal pain or bloating. ${ }^{26,27}$

Bloating is the second most common reported symptom in patients with IBS following abdominal pain. ${ }^{28}$ In a study from USA which assessed bloating in 542 IBS patients, $76 \%$ of the patients reported that they experienced bloating. ${ }^{29}$ Other study revealed that more than $90 \%$ of patients with IBS suffered from bloating. ${ }^{30}$ In addition, on comparing constipation dominant IBS (IBS-C) with diarrhea dominant IBS (IBS-D), the prevalence of bloating was higher in IBS-C. ${ }^{31}$

A survey from the USA suggested that more than $65 \%$ of patients with bloating rated their symptom as moderate to severe, and $54 \%$ of patients complained of decreased daily activity due to bloating. Furthermore, $43 \%$ of patients took medication for bloating or needed medication. ${ }^{22}$ 


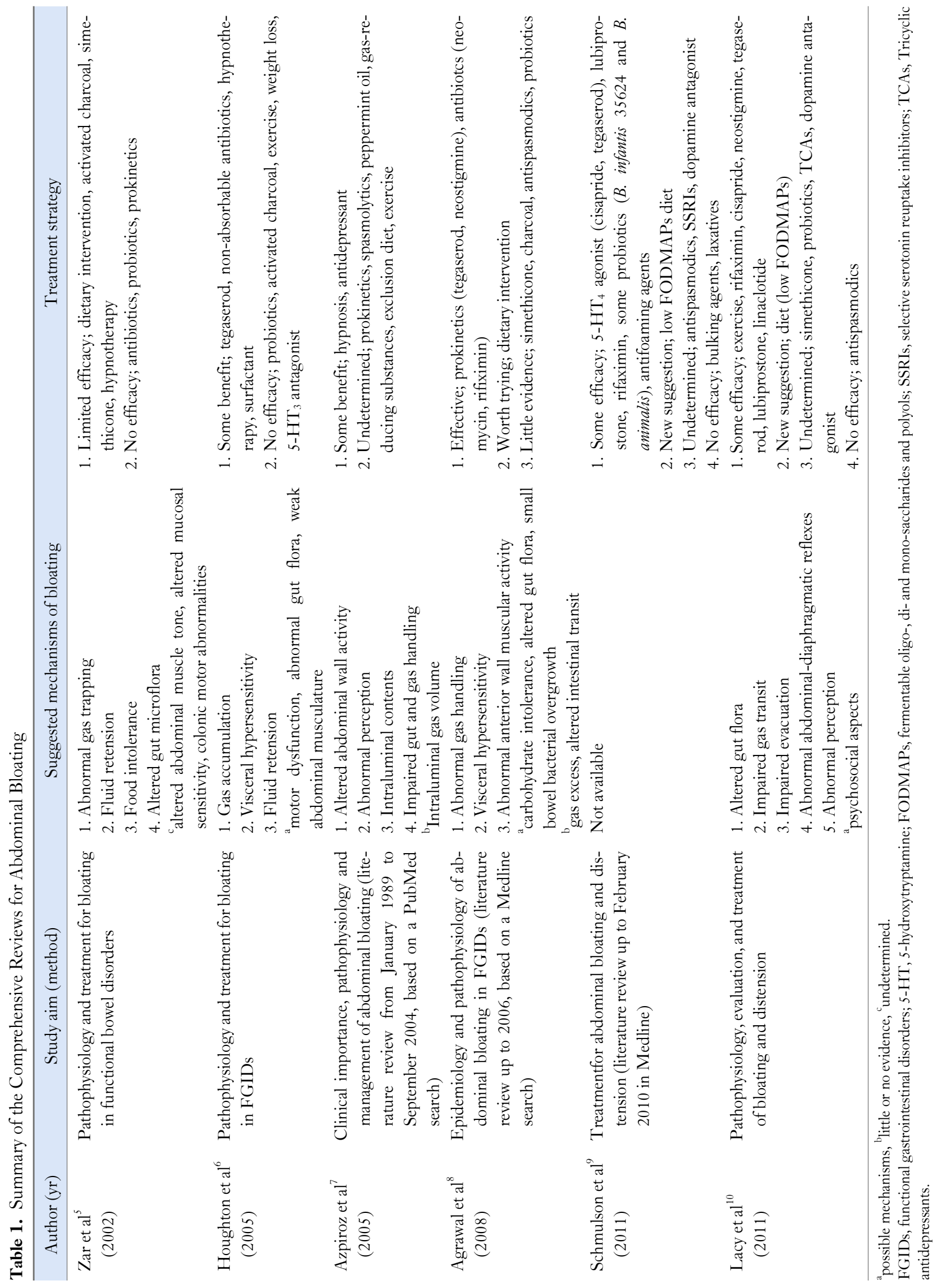




\section{Pathophysiology}

\section{Abnormal Gut Microbiota}

The GI tract microbiota play an important role in host immune system, and there are more than 500 different species of GI microbiota in adult, which mostly are obligate anaerobes. ${ }^{10}$ Only a fraction of these organisms can be cultured; therefore, the understanding of the functions of various microbes in the GI tract is still limited. However, researches over the past decades have shown that altered colonic flora were found in stool samples of patients with IBS. ${ }^{32-34}$ Parkes et $\mathrm{al}^{35}$ suggested that the GI microbiota can be divided into 2 ecosystems; the luminal bacteria and the mucosa-associated bacteria (Fig. 1). Luminal microbiota form the majority of the GI tract flora, and they play a key role in bloating and flatulence in IBS through carbohydrate fermentation and gas production. ${ }^{35}$

One comprehensive study of the luminal microbiota in IBS examined the fecal samples of IBS subgroups (diarrhea predominant, constipation predominant and mixed subtype) and the controls using $16 \mathrm{~S}$ ribosomal RNA (rRNA) sequencing. It has been shown that fecal microbiota are significantly altered in IBS. That is, some patients with IBS seem to have different patterns of colonization with coliforms, such as lactobacillus and bifidobacterium compared to the controls. ${ }^{36}$ Similar study from Korea using $16 \mathrm{~S}$ rRNA gene signatures also has demonstrated significant differences in diversity and dominance between IBS and non-IBS fecal samples. ${ }^{37}$ In addition, these microbial changes altered protein

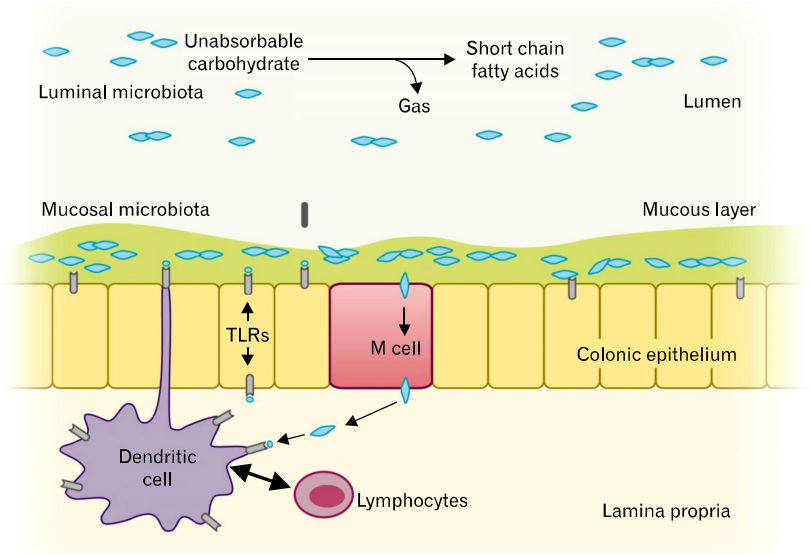

Figure 1. Luminal and mucosal colonic microbiota and their roles in gut homeostasis. Modified from Parkes et al. ${ }^{35}$ and carbohydrate metabolism in the gut. ${ }^{37} \mathrm{~A}$ study from Japan also showed higher counts of Veillonella $(P=0.046)$ and Lactobacillus $(P=0.031)$ in IBS patients than in controls. Besides, they expressed significantly higher levels of acetic acid $(P=0.049)$, propionic acid $(P=0.025)$ and total organic acids $(P=0.014)$ than controls, which is related to symptoms such as abdominal pain, bloating and changes in bowel habits. ${ }^{38}$ Another study demonstrated that the patients with IBS produced more $\mathrm{H}_{2}$ but the total gas excretion was similar in both IBS patients and controls. ${ }^{39}$ This may be associated with alteration in colonic fermentation by hydrogen-consuming bacteria, which may be an important factor in the pathogenesis of IBS.

Collins et $\mathrm{al}^{40}$ have proposed that disruption of the balance between the host and intestinal microbiota produces changes in the mucosal immune system from microscopic to overt inflammation and this also results in changes in gut sensory-motor function and immune activity. Besides, these altered microflora may produce differences in fermented gas type and volume, which may be the causes of symptom in patients with bloating. $36,40,41$

There have been some reports to verify the relationship between the types of gas produced by colonic microflora and bloating. The low producers of methane reported significantly increased bloating and cramping after ingestion of sorbitol and fiber, and the high producers of methane revealed lower prevalence of severe lactulose intolerance than low producers. Hence, the role of methanogenic flora may be important in the pathogenesis of bloating. $^{42,43}$

\section{Small Intestinal Bacterial Overgrowth}

The patients with IBS who specifically complain of bloating have been reported to have increased gas production from bacterial fermentation caused by small intestinal bacterial overgrowth (SIBO). Pimentel and colleagues had established the concept that SIBO might be a major pathogenesis of IBS. ${ }^{44}$ Moreover, several studies found significant improvement of symptoms such as abdominal pain or bloating, when they were treated with antibiotics. $^{44-46}$ These findings, however, have not been supported by other studies; ${ }^{47-49}$ they found mildly increased counts of small intestinal bacteria by culture to be more common in IBS, but the breath $\mathrm{H}_{2}$ concentration was not significantly different between IBS patients and controls. ${ }^{48}$ Also, there was no correlation between bacterial alteration and symptom pattern, and even lactulose breath test was considered as an unreliable method to detect an association between bacterial overgrowth and IBS. ${ }^{47,48}$ 
In another study, breath hydrogen concentration was similar in IBS group and control group, and did not correlate with pain ratings in IBS patients, owing to the lack of objective diagnostic measures and inconsistent data. ${ }^{51}$

It is unclear whether changes in small bowel bacterial flora could contribute to bloating in IBS patients, thus further studies are required to confirm these observations.

\section{Intestinal Gas Accumulation}

In the fasting state, the healthy GI tract contains only about $100 \mathrm{~mL}$ of gas distributed almost equally among 6 compartments - stomach, small intestine, ascending colon, transverse colon, descending colon and distal (pelvic) colon. Postprandial volume of gas increases by about $65 \%$, primarily in the pelvic colon. ${ }^{12}$ The excessive volume of intestinal gas has been proposed as the likely cause of bloating and distension, and many researchers have attempted to determine this view. A few studies using plain abdominal radiography demonstrated that intestinal gas volume was greater in patients with IBS than in controls (54\% vs. 118\%), however, the correlation between intra-abdominal gas contents and bloating was poor. ${ }^{52,53}$ The vast majority of studies do not support that excessive gas induces bloating or abdominal pain. Lasser et $\mathrm{al}^{54}$ conducted a study using argon washout technique, which demonstrated no differences in the accumulation of intestinal gas between patients with bloating and healthy subjects. More recent studies using CT scans combined with modern imaging analysis software have also shown that excess gas was not associated with abdominal bloating in most patients. ${ }^{3}$ Thus, these observations suggest that increased volume of gas may not be the main mechanism of bloating, but rather impaired gas transit or distribution are more often the sources of problem.

\section{Altered Gut Motility and Impaired Gas Handling}

Various abnormal motility patterns have been described in IBS patients, but none of those parameters can be used as diagnostic markers. ${ }^{55}$ Some authors have suggested that slow transit of food representing alteration in gut motility is related to bloating in IBS-C patients. ${ }^{56}$ Also in a traditional experiment, normal volunteers being made constipated with loperamide, an agent known to slow transit, experienced bloating. ${ }^{57}$ Recently, IBS-C patients with delayed orocecal and colonic transits have shown abdominal distension rather than bloating. ${ }^{15}$ Although delayed gastric emptying and slow intestinal transit in IBS-C patients were reported in many Asian studies, there are still controversies to de- fine these motor disturbances as unique features in Asian IBS patients. Besides, the association between altered gut motility and IBS symptoms is pretty obscure. ${ }^{58}$ A recent study has also suggested that altered colon transit is of no or minor importance for IBS symptoms such as bloating or pain. ${ }^{59}$

However, there are some different points with respect to the intestinal gas handling or transit. In a study by Serra et al, ${ }^{60}$ they have shown that infused gas into the jejunum resulted in distension and abdominal bloating in most of the IBS patients ( 18 of 20 ), while only $20 \%$ ( 4 of 20) of control subjects developed symptoms like that. Another study using gas challenge technique has demonstrated that small intestinal gas transit (especially, jejunum) was more prolonged in patients with bloating than in controls, whereas colonic transit was normal. ${ }^{61}$ These data support that impaired small intestinal gas handling could be a mechanism of IBS or gas-bloating. Furthermore, a gas challenge test in healthy subjects during blocked rectal gas outflow showed that abdominal distension by girth measurement was similar in the jejunal and rectal infusion experiments, whereas abdominal symptoms including bloating were more significant in jejunal group. ${ }^{62}$ These data indicate that gas related symptom perception is determined by intraluminal gas distribution, whereas abdominal distension depends on the volume of intestinal gas. Besides, the patients with IBS or FB are considered to evacuate intestinal gas less effectively, so that they are more likely to have symptoms of abdominal distension. ${ }^{63,64}$ This aspect of bloating's mechanism has not been considered to be very relevant, but some researchers are interested in this view owing to the observations of anorectal function, especially in patients with constipation. Constipated patients with bloating plus distension exhibited a greater degree of anorectal dysfunction than those without distension. Moreover, self-restrained anal evacuation also increased symptom perception, while impaired gut propulsion caused by intravenous glucagon did not. ${ }^{63,64}$

Taken together, ineffective anorectal evacuation as well as impaired gas handling may be possible mechanisms of abdominal distension and bloating. However, the data on the link between altered food transit of gut and bloating are not consistent, although they probably account for bloating in some of the IBS patients. $^{56,57}$

\section{Abnormal Abdominal-diaphragmatic Reflexes}

The abdominal cavity is determined by the placement of the walls of abdominal cavity including diaphragm, vertebral column and abdominal wall musculature. Even if there is no increase in 
intra-abdominal volume, a change of the position of abdominal cavity components may produce abdominal distension. ${ }^{7}$ Thus, there have been some efforts to evaluate the relationship between bloating and lumbar lordosis or weakened abdominal muscles. In one classic report, Sullivan suggested that the patients with bloating have weak abdominal muscles and frequently had recently gained weight than controls. ${ }^{65}$ But another study measuring upper and lower abdominal wall activities using surface electromyography has suggested that there were no differences in abdominal muscle activities between the patients and the controls. ${ }^{66}$ Moreover, in an early CT study, some IBS patients showed a tendency of lumbar lordosis but not consistent, and a change in lumbar lordosis did not correlate in any way with the changes in abdominal girth. Also, there were no noticeable changes in position of the diaphragm. ${ }^{67}$

Tremolaterra et $\mathrm{al}^{68}$ reported that intestinal gas load was associated with a significant increment in abdominal wall muscle activity in healthy subjects. In contrast, the response to gas infusion was impaired in patients with bloating, and rather a paradoxical relaxation of the internal oblique muscles was noted. ${ }^{68}$ Further study using modern CT analysis with electromyography from Barcelona group has provided a novel concept of abnormal abdomino-phrenic reflexes for abdominal bloating and distension. Since then, several studies have demonstrated that abdomino-phrenic dyssynergia is one of main factors for abdominal distension and bloating. In healthy adults, colonic gas infusion increases anterior wall tone and relaxes the diaphragm at the same time. On the contrary, patients with bloating have shown diaphragmatic contraction (descent) and relaxation of the internal oblique muscle with the same gas load. ${ }^{4,69,70}$

\section{Visceral Hypersensitivity}

The sensation of bloating may originate from abdominal viscera in patients with FGIDs, in whom normal stimuli or small variations of gas content within the gut may be perceived as bloating. Indeed, it has been well recognized that the patients with IBS have lower visceral perception threshold than healthy controls, ${ }^{1,71}$ and it has been speculated that this process might be associated with the sensation of bloating. Kellow et al ${ }^{72}$ revealed that threshold for perception of small bowel contraction was lower than normal in some patients with IBS. Also, altered rectal perception assessed by phasic balloon distension has been reported in IBS patients. ${ }^{73}$ In addition, a gas challenge test proved a role of sensory disturbances in IBS patients, ${ }^{60}$ and recent clinical experiment has demonstrated that bloating without visible distension is associated with visceral hypersensitivity. ${ }^{74}$

The autonomic nervous system may also contribute to modulation of the visceral sensitivity. Sympathetic activation is known to increase the perception of intestinal distention in FD patients; likewise, autonomic dysfunction could affect the visceral sensitivity in IBS patients. ${ }^{75-77}$ This mechanism may play a role in bloating. Moreover, it has been proposed that visceral perception may be influenced by cognitive mechanism. That is, IBS patients with bloating pay more attention to their abdominal symptoms, which is a kind of hyper-vigilance. ${ }^{78}$ Also, a report indicated that female patients with IBS had worsening of abdominal pain and bloating during their peri-menstrual phase, at which time heightened rectal sensitivity might have contributed to bloating, but not to distension. ${ }^{24,79}$ Taken together, altered sensory threshold combined with altered conscious perception may explain the mechanism of bloating.

\section{Food Intolerance and Carbohydrate Malabsorption}

It is well recognized that dietary habits may be responsible for abdominal symptoms, and there have been efforts to prove the relationship between diet and IBS symptoms. Fiber overload has long been regarded as worsening factor of IBS symptoms through decreased small bowel motility or intraluminal bulking. ${ }^{80,81}$ In addition, lactose intolerance may contribute to symptom development in IBS patients. In the small intestine, disaccharides are split by intestinal enzymes into monosaccharides which are then absorbed. If this process is not carried out, the disaccharide reaches the colon, in turn is split by bacterial enzymes into short chain carbonic acids and gases. Hence, malabsorption of lactose may produce the symptom of bloating in patients with IBS or FB. ${ }^{11,82-84}$ Additionally, a new hypothesis is proposed, by which excessive delivery of highly fermentable but poorly absorbed short chain carbohydrates and polyols (collectively termed FODMAPs; fermentable oligo-, di- and mono-saccharides and polyols) to the small intestine and colon may contribute to the development of GI symptoms. FODMAPs are small molecules that are osmotically active and very rapidly fermentable compared with long-chain carbohydrates. These molecules induce relatively selective bacterial proliferation, especially of bifidobacterium, and it has been demonstrated indirectly that these can lead to expansion of bacterial populations in distal small intestine. ${ }^{85-87}$ Thus, high FODMAP diet has demonstrated prolonged hydrogen production in the intestine, colonic distension by fermentation, increased colonic fluid delivery by osmotic load within the bowel lu- 
men, and GI symptom generation. ${ }^{88,89}$

\section{Intraluminal Contents}

Levitt et al ${ }^{90}$ suggested that abdominal bloating might develop without gas retention, but by other gut contents. They had undertaken randomized, double-blind, crossover study of gaseous symptoms by observing the responses of healthy subjects to dietary supplement with lactulose or 2 types of fibers (psyllium or methylcellulose). In lactulose group, gas passages, subjective perception of rectal gas and breath hydrogen excretion were significantly increased, but not in fiber groups. However, the sensation of bloating was increased in all 3 groups. Thus, it has been proposed that increased intra-abdominal bulk, not gaseous filling, might be a cause of abdominal bloating. ${ }^{90}$ In another study, bran accelerated small bowel transit and ascending colon clearance without causing symptom in controls, but small bowel transit has not further been accelerated in IBS patients with bloating. Thus, they speculated that bran might cause increased bulking effect in the colon, which led to the exacerbation of bloating in IBS patients. ${ }^{91}$ Francis and Whorwell ${ }^{80}$ even proposed that use of the bran in IBS should be reconsidered, because excessive consumption of bran might give rise to symptoms such as bloating in IBS patients. Although more studies are needed for further understanding of their relationship, it could be possible that intraluminal bulking aggravates the bloating in some IBS patients.

\section{Hard stool/Constipation}

Many constipated patients complain of bloating. ${ }^{14}$ Also there is a tendency of its being more common in IBS-C patients than IBS-D patients, though it is not statistically significant in some studies. ${ }^{31,92-94}$ Distension of the rectum by retained feces slows small intestinal transit as well as colonic transit, probably explaining the aggravated bloating in constipated patients. ${ }^{15,56}$ Thus it seems reasonable that constipation or hard/lumpy stool induces alteration of gut motility and thus maybe increases bacterial fermentation. In addition, constipation may accelerate bloating by intraluminal bulking effect in the same manner as bran.

\section{Psychological Aspects}

Bloating is a frequent complaint of women with IBS. Park et $\mathrm{al}^{95}$ proposed that there was a tendency to increase the index of psychological distress when the bloating was more severe. Also, patients with bloating revealed increased anxiety and depression, which allows the hypothesis that psychological distress may contribute to the perceived severity of bloating. ${ }^{96}$ Additionally, in large population surveys, bloating was significantly related with psychiatric dysfunction such as major depressive disorder, panic disorder and sleeping difficulties. ${ }^{97,98}$ Nevertheless, other studies have failed to demonstrate the relationships between psychological distress and either bloating or distension. ${ }^{14,99}$ However, it is unclear whether or not there is an actual relationship between bloating and psychosocial distress, and further studies are needed to demonstrate it.

\section{Gender and Sex Hormones}

In a population based study in USA, female gender was significantly associated with increased symptoms of bloating and distension in IBS, and similar findings have been reported so far. $^{21,100-102}$ Although the question of the gender role in IBS has been raised from many studies, the mechanisms of gender differences in bloating and distension are unclear. Some studies have suggested that bloating is one of the frequent symptoms of menstruation as aforementioned. ${ }^{24,25}$ Hormonal effect has also been speculated, that is, the variation of reproductive hormones throughout the menstrual cycle and after the menopause may influence the gut motility and visceral perception. ${ }^{24,79,103}$ Additionally, difference in symptom expression by gender is presented as a potential explanation. ${ }^{31}$ Although more investigations regarding the underlying mechanisms for these disparities remain to be determined, it seems to be possible to speculate that the hormonal fluctuation may contribute to bloating in female IBS patients.

\section{Treatment}

\section{Antibiotics}

There has been an increasing acceptance of the use of the antibiotics to treat IBS symptoms, and it is plausible based on the presumption that altered gut flora or SIBO may contribute to gaseous distension or bloating symptom. ${ }^{44,104,105}$

Although some questions have been raised regarding the validity of the lactulose breath test in diagnosis of SIBO and the possibility of overdiagnosis, ${ }^{106}$ much more data support the clinical use of antibiotics in this condition. Specifically, rifaximin, a rifamycin derivative, has largely been studied, and it showed superiority to placebo in relieving bloating in IBS or in patients who were diagnosed as SIBO (Table 2). As rifaximin is a non-absorbable antimicrobial agent, the risk of side effects or emergence of resistant organisms is expected to be low; therefore it is suitable for chronic administration. ${ }^{44-46,107,108}$ Recently, a phase 3 multi- 


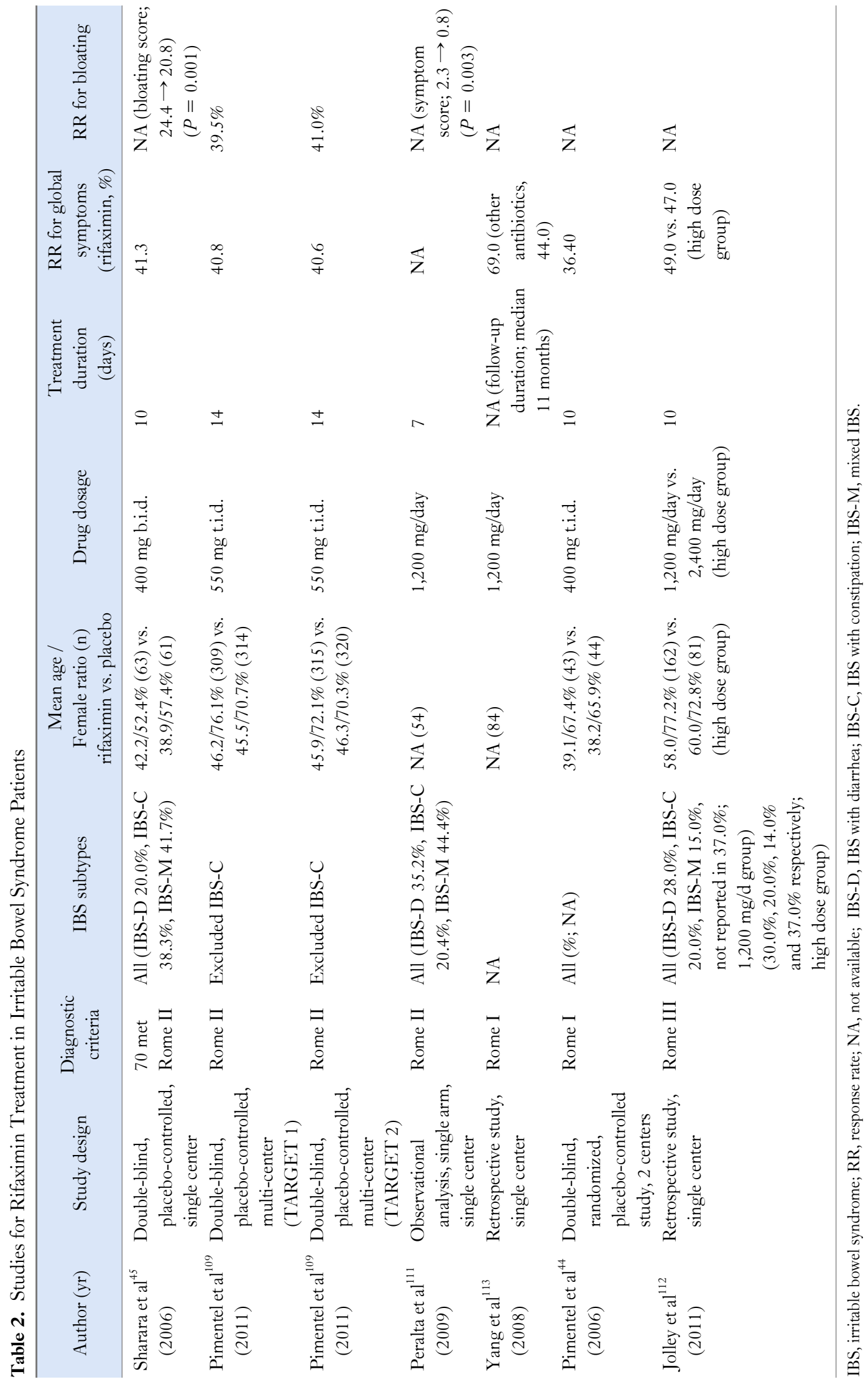


center trial proved that rifaximin provided significant improvement of IBS symptoms including abdominal pain and bloating in non-constipated IBS patients. ${ }^{109}$ Pimentel et al ${ }^{110}$ also suggested that neomycin normalized lactulose breath test and it contributed to the reduction of bloating in IBS patients. Besides, there have been several retrospective or observational studies, which support the efficacy of rifaximin treatment in IBS patients. Specifically, rifaximin turned the lactulose breath test to negative and significantly reduced the overall symptom scores. ${ }^{111}$ Also, high dose rifaximin treatment $(2,400 \mathrm{mg} /$ day $)$ was proved to be effective in patients who had incomplete response to usual dose of rifaximin. ${ }^{112}$ Another retrospective study has revealed that rifaximin is superior to other antibiotics, such as neomycin, doxycycline, amoxicillin/clavulanate and ciprofloxacin in patients with IBS. ${ }^{113}$ Therefore, antibiotics like rifaximin could be considered as a short course therapeutic regimen for bloating, mainly in IBS without constipation. Further studies are needed to determine how long these antibiotics should be given and whether drug resistance will be a problem.

\section{Probiotics}

Alteration in gut microbiota may produce or perpetuate the symptoms of bloating or distension, therefore many researchers postulated that modification of the gut microflora could improve gas related symptoms. ${ }^{39}$ One placebo-controlled study conducted in IBS patients revealed a beneficial effect of Bifidobacterium infantis and they suggested immune-modulating role of that organism. ${ }^{114}$ Another multicenter, clinical trial in women with IBS also showed that $B$. infantis relieved many of the symptoms of IBS, but just at a specific dosage $\left(1 \times 10^{8} \mathrm{CFU} / \mathrm{mL}\right) .{ }^{115}$ In addition, more recent experiments have shown that some probiotic strains significantly alleviate the bloating as well as overall symptoms. ${ }^{116,117}$ One study from Korea has shown that multi-species probiotics given to IBS patients are effective in the relief of bloating, albeit not statistically significant over placebo. ${ }^{118}$ In the most recent meta-analysis of probiotics for lower GI symptoms, specific probiotics are recommended in the management of bloating in IBS patients as moderate grade of evidence along with $70 \%$ level of agreement. ${ }^{119}$

On the contrary, many other studies have failed to prove favorable effects of the probiotics. Kim et $\mathrm{al}^{120}$ evaluated the effectiveness of VSL\#3, a composite probiotic containing Bifidobacterium, Lactobacillus and Streptococcus in IBS patients. VSL\#3 reduced flatulence scores and retarded colonic transit without altering bowel function, but there was no significant reduction in bloating score with VSL\#3. ${ }^{120}$ Some experimental studies from Korea showed a trend towards amelioration of bloating, but failed to prove beneficial effect over placebo. ${ }^{121,122}$ In addition, several other studies using lactobacillus strains reported unfavorable effect on bloating in IBS (Table 3). ${ }^{41,123,124}$ Most of the studies were relatively small and there have been inconsistent results regarding the efficacy of probiotics on bloating. Hence, larger and well-designed trials are needed to prove whether the probiotics are reasonable to treat patients with bloating.

\section{Prokinetics}

Prokinetics have been used in the treatment of bloating in FD traditionally, in spite of the weak evidence for correlation between symptoms and underlying pathophysiological mechanisms. A number of studies have shown the beneficial effect of prokinetics such as dopamine antagonist, muscarinic antagonist, and serotonergic agents in FD, but studies conducted in IBS patients are relatively rare (Table 4$)$. Several studies have suggested that cisapride, a 5-hydroxytryptamine $4\left(5-\mathrm{HT}_{4}\right)$ receptor agonist, significantly improves postprandial bloating in FD patients. ${ }^{125,126}$ Levosulpiride turned out to be as effective as cisapride in the treatment of FD symptoms, such as bloating. ${ }^{127}$ Acotiamide, a novel prokinetic agent, also provided relief of bloating in FD patients in a small study. ${ }^{128}$

Some researchers tried to investigate the efficacy of tegaserod, a selective $5-\mathrm{HT}_{4}$ partial agonist, in patients with IBS-C whose main symptom was not diarrhea, and they suggested significant relief in bloating with tegaserod. ${ }^{129-132}$ However, tegaserod was withdrawn from the market in 2007 due to possible adverse cardiovascular effects. Additionally, neostigmine, a potent prokinetic drug, also exhibited significant effect in reducing objective abdominal distension as well as bloating in IBS or FB patients. ${ }^{133}$ On the other hand, some other studies do not agree with the favorable action of prokinetics in IBS. One double-blind trial suggested that cisapride was not superior to placebo in the treatment of bloating and other abdominal symptoms of IBS, but it reduced difficulty of stool passage. ${ }^{134}$ However, cisapride was also removed from the market due to the side effect. Another study conducted in IBS patients to evaluate the efficacy of domperidone showed no significant improvement of bloating. ${ }^{135}$ In a small experimental study, pyridostigmine reduced the severity of bloating, but it did not reach the statistical difference across groups. ${ }^{3}$ Although there are conflicting evidences regarding the effect of prokinetics on bloating, some of the prokinetics could be a treatment option for bloating. 


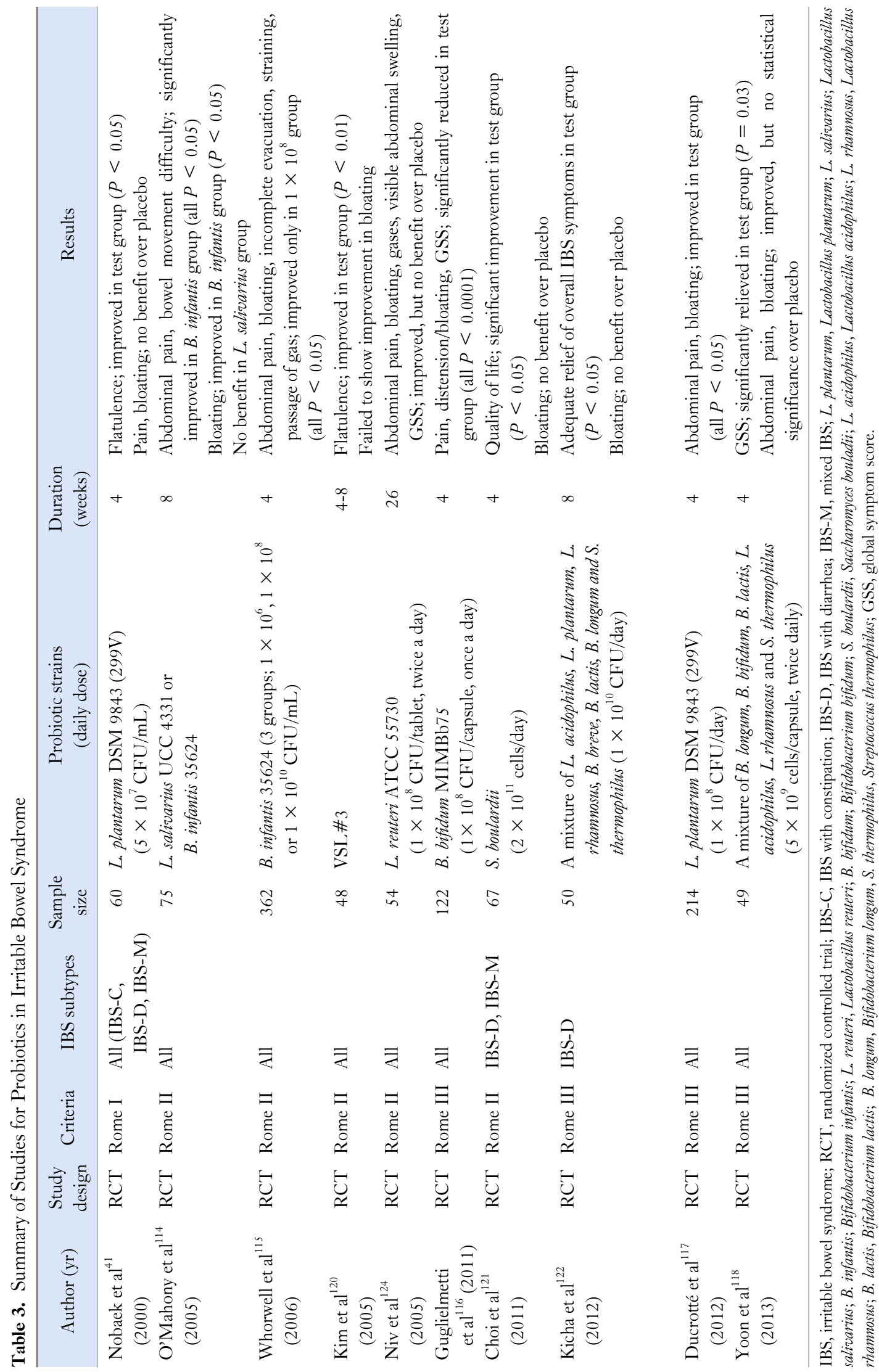



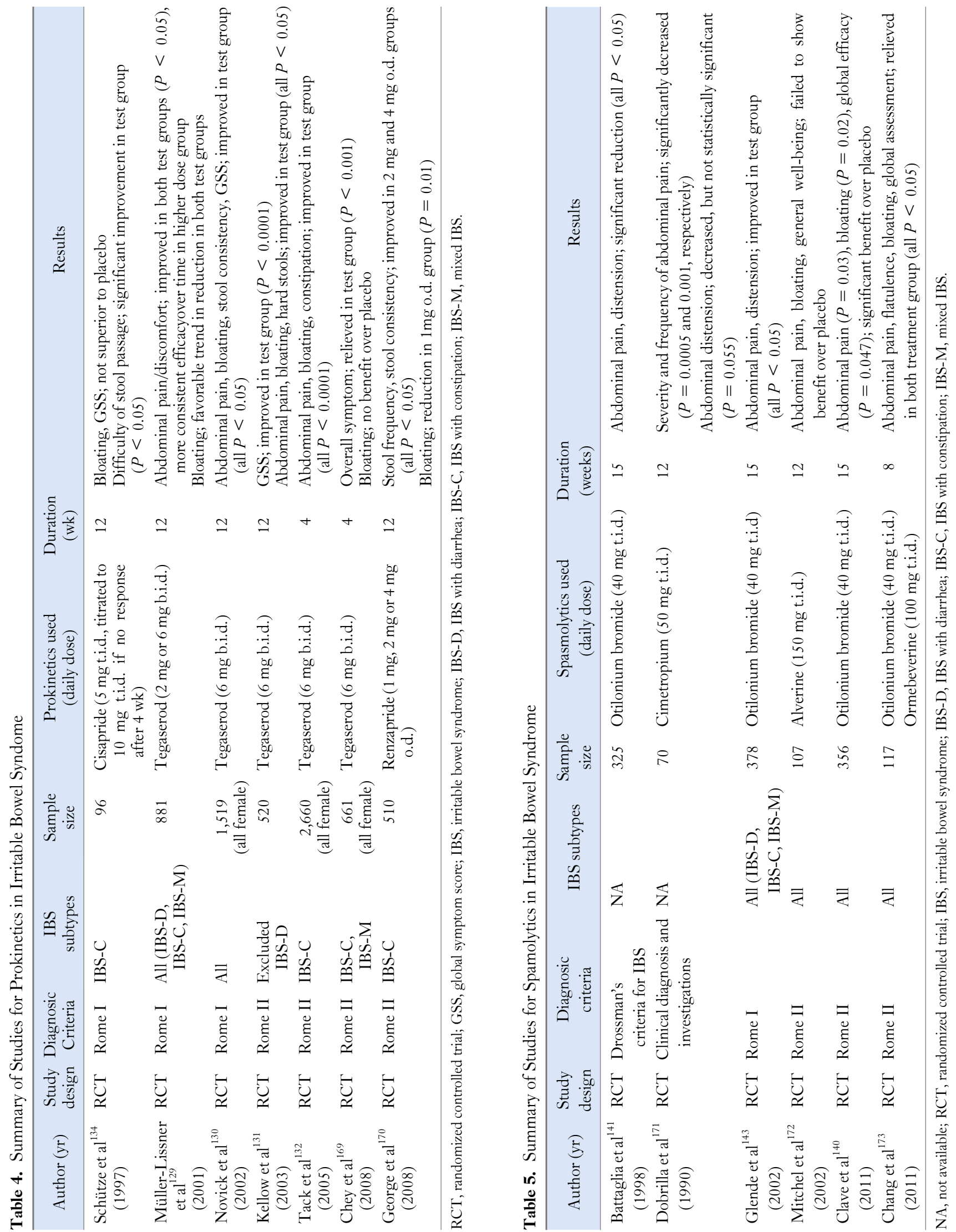


\section{Antispasmodics}

Various types of antispasmodics have been commonly used to relieve the symptoms of IBS, given the presumption that altered GI motility and smooth muscle spasm may give rise to the IBS symptoms. ${ }^{136}$ Several studies have shown the efficacy of these drugs in IBS symptoms such as bloating, but some do not (Table 5). ${ }^{137-142}$ Also data are limited since many of these agents (e.g., mebeverine, otilonium and trimebutine) are not licensed in the USA. There have been several reports that support the beneficial effect of otilonium. ${ }^{141,143}$ Besides, in a few studies, peppermint oil, considered as a natural spasmolytic agent due to its calcium influx blocking effect, was also superior to placebo in reduction of abdominal distension and bloating. ${ }^{144,145}$ One systematic review evaluated the efficacy and tolerability of mebeverine. In the meta-analysis, it was effective in the clinical improvement of abdominal pain or distension, but it did not reach a statistical significance. ${ }^{146}$ Taken together, antispasmodics have shown some efficacy in the treatment of bloating, but the study results were inconsistent and it is difficult to draw definite conclusion about these conflicting views. Thus, larger studies are needed.

\section{Dietary Interventions}

Food intake may play a key role in perpetuating symptoms in IBS patients, so a careful history taking for diet should be taken. Many retrospective observational studies have shown that the reduced intake of large amounts of highly fermentable, poorly absorbed short chain carbohydrates (FODMAPs) may reduce bloating in IBS patients. ${ }^{147-149}$ Finally, the low FODMAP diet was developed at Monash University in Melbourne, ${ }^{150}$ and recently, the first prospective study confirming the efficacy of low FODMAP diet for IBS patients was reported. Besides, patients with IBS who had also fructose malabsorption were significantly more likely to respond to the low FODMAP diet than those without fructose malabsorption (Table 6). ${ }^{151}$

\section{Gas Reducing Substances}

One of the earliest pharmachological modalities used in treating distension and bloating was antifoaming agent, and a silicone derivative with surfactant, officially designated as "simethicone" is known as a traditional antifoaming agent, by which gases are evacuated and absorbed from the gut. ${ }^{152}$ As most of the studies which investigated the therapeutic benefit of those agents were carried out in the subset of patients who have FD, their efficacy in IBS patients seems questionable. Bernstein et $\mathrm{al}^{153}$ reported that

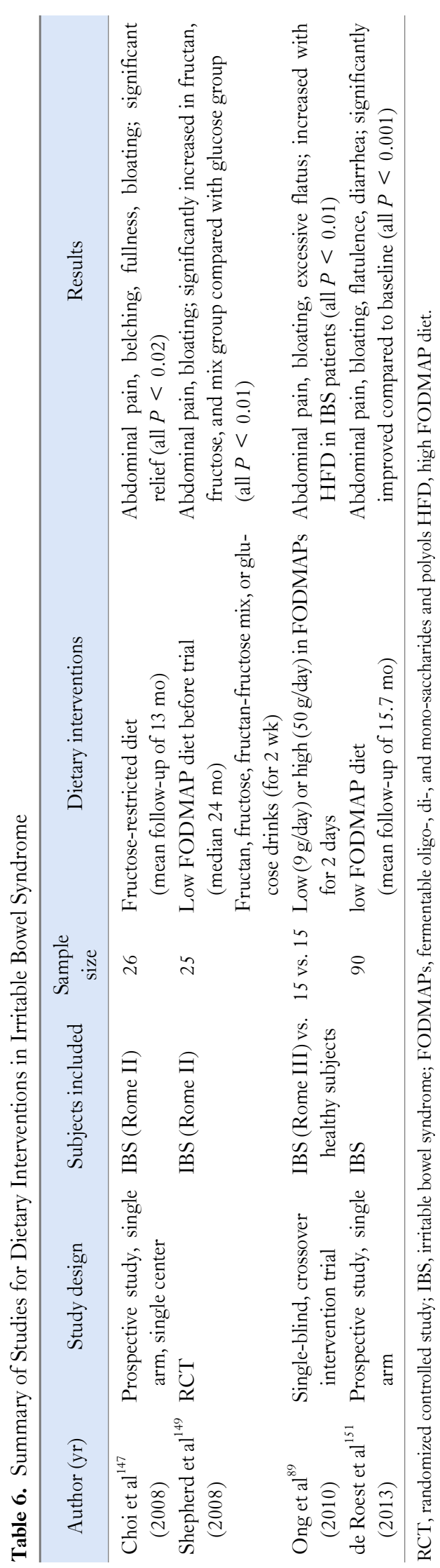


simethicone significantly relieved the frequency and severity of gas-related symptoms in patients with FGID. Holtmann ${ }^{154}$ also conducted a randomized, placebo-controlled trial of simethicone, and suggested that simethicone was significantly better than placebo for overall symptom control in FD patients, in spite of unfavorable effect for bloating. More recently, prospective, multicenter trial to demonstrate a favorable action of activated charcoal-simethicone combination therapy revealed that the severity of fullness and bloating was significantly decreased in the therapy group compared with placebo (Table 7). ${ }^{155}$

\section{Stimulants of Fluid Secretion}

Lubiprostone and linaclotide are novel agents recently approved by the USA Food and Drug Administration, that enhance fluid secretion into the gut lumen and accelerate intestinal transit. These properties are considered to play a role in treatment of constipation, thus a number of clinical trials focusing in the chronic constipation or IBS-C have been conducted (Table 8). In 2 phase III trials, lubiprostone significantly improved the overall IBS symptoms including bloating in IBS-C. ${ }^{156,157}$ Several multicenter, randomized trials of linaclotide in chronic constipation or IBS-C also demonstrated the beneficial effect in relieving abdominal bloating. ${ }^{158,159}$ Thus so far, these 2 novel drugs offer a reasonable therapeutic approach for bloating mainly in IBS-C and functional constipation patients.

\section{Antidepressants}

Antidepressants such as selective serotonin reuptake inhibitor (SSRI) or tricyclic antidepressant (TCA) are believed to alleviate symptoms in FGIDs on the basis of their visceral analgesic properties as well as psychological aspects. However, one small study conducted in IBS patients with visceral hypersensitivity revealed that fluoxetine, one of the SSRI, was effective only in abdominal pain, not in other symptoms such as bloating. ${ }^{160}$ Paroxetine was also evaluated in IBS patients who did not respond to high fiber diet. Overall well-being sensation was improved more with paroxetine than with placebo, but abdominal bloating was not. ${ }^{161}$ However, there were also some positive results. That is, the SSRI, citalopram significantly improved abdominal bloating compared with placebo, though the therapeutic effect was independent of the effect on anxiety, depression and colonic sensitivity (Table 9). ${ }^{162}$ Taken together, the results for the treatment of bloating and distension with antidepressants are partly contradictory, and there were few studies which explained the effect of TCA on bloating. Hence, larger, well-designed trials

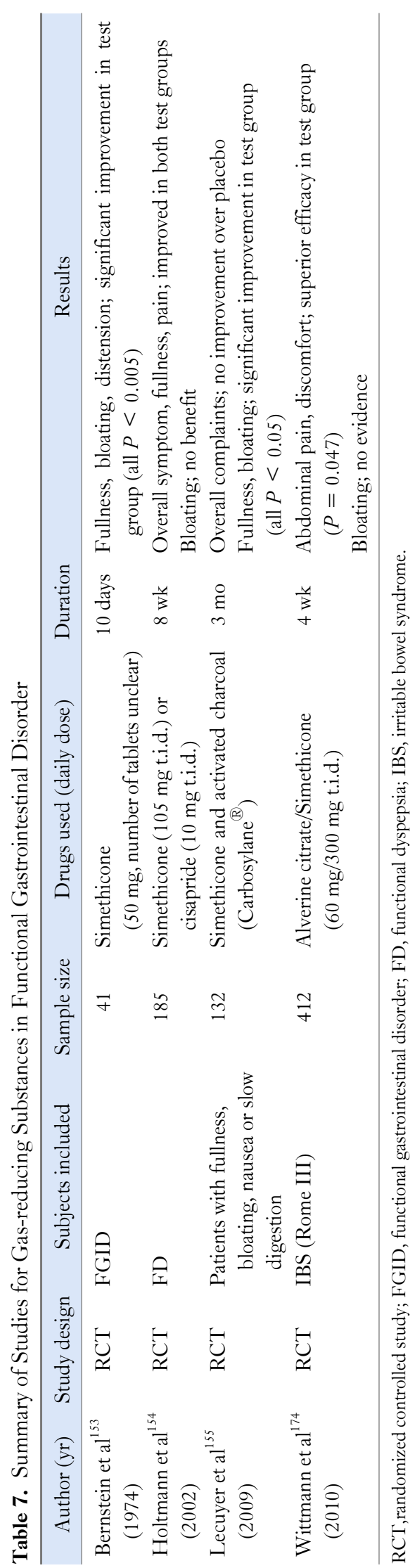




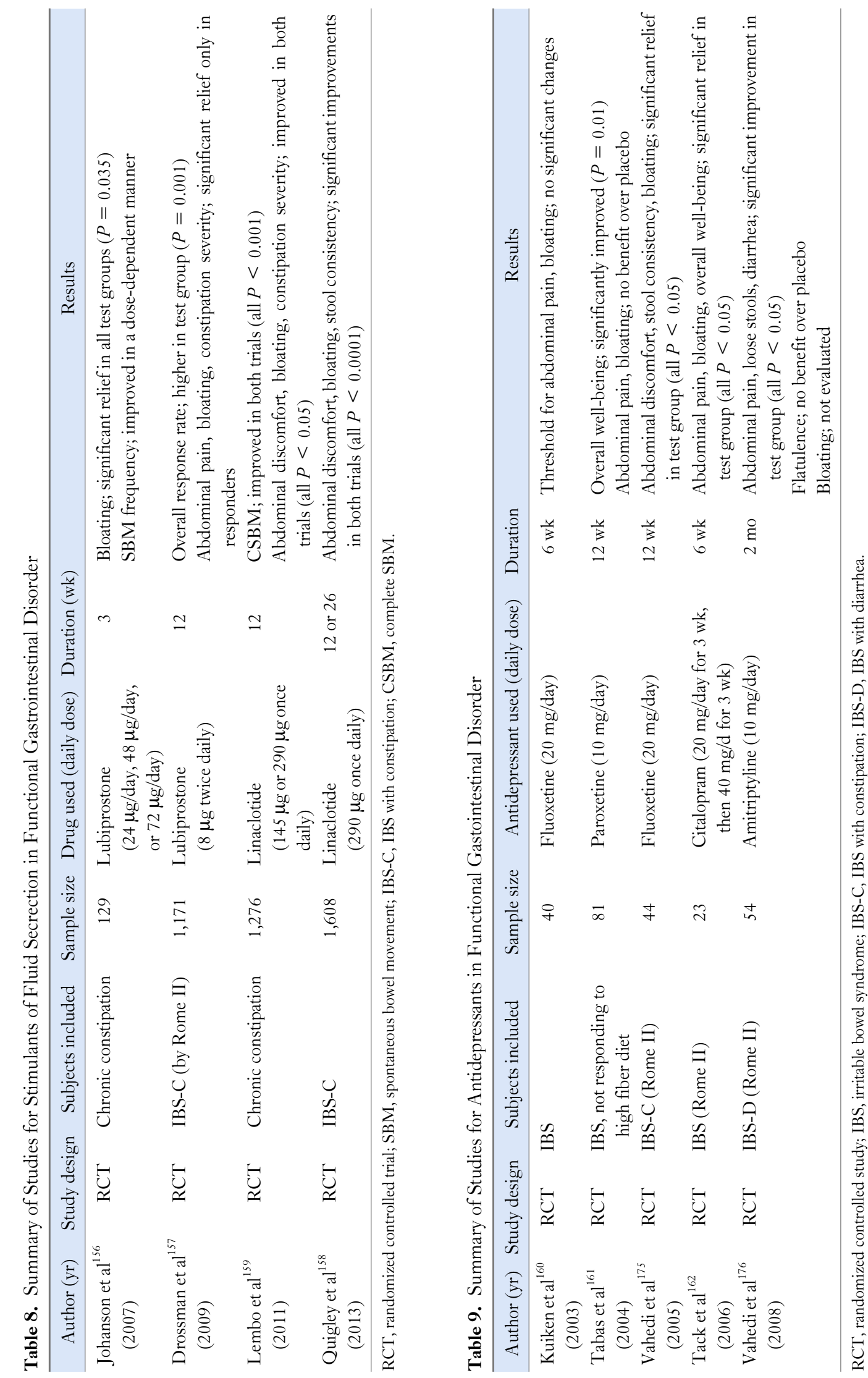




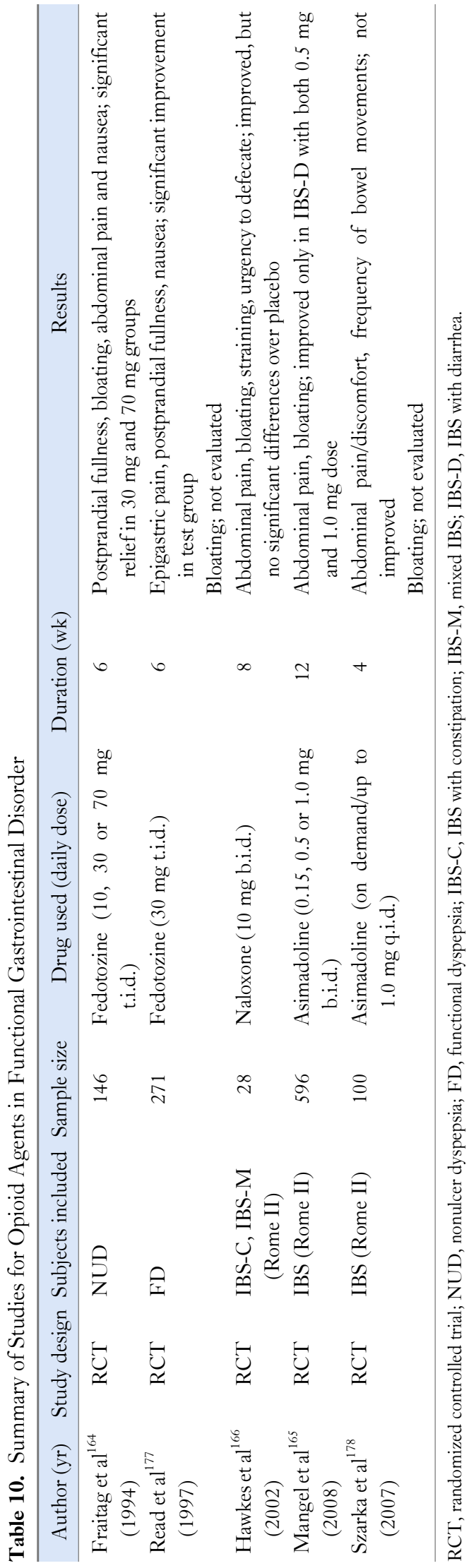

with SSRIs and TCAs are warranted to identify the efficacy of these drugs on bloating and distension.

\section{Opioid Agents}

There have been a few reports that propose the usefulness of opioid agents in IBS patients (Table 10). The kappa receptor agonist, fedotozine has been shown to increase the threshold of perception to colonic distension and reduce visceral sensation. ${ }^{163}$ It has also demonstrated its superiority to placebo in relieving postprandial fullness and bloating in FD patients. ${ }^{164}$ In a phase II trial, asimadoline, a novel kappa-opioid agonist, has yielded excellent efficacy results on pain and bloating in IBS-D patients. ${ }^{165}$ A small study has suggested that naloxone is beneficial in reducing the bloating score in IBS-C or IBS-M patients, but there were no significant differences in the results with naloxone and placebo. ${ }^{166}$ Though a recent review also makes a suggestion of the use of opioid agonists in IBS-D patients, ${ }^{167}$ their role in bloating is uncertain to date.

\section{Summary}

Abdominal bloating is a frequent and bothersome, but poorly understood clinical problem. The terms of bloating and distension are often confused, but these 2 symptoms should be considered to be separate, as they probably have different pathophysiological mechanisms. The possible mechanisms of bloating are complex and maybe various mechanisms are combined in symptom generation. Important mechanisms of bloating are impaired gas handling and hypersensitivity. Also, recent evidences are beginning to emphasize that patients with bloating may have an altered bacterial flora, SIBO, and abdomino-phrenic dyssynergia. Other less-established factors for bloating are food intolerance, intraluminal bulking and psychological factors (Fig. 2).

On approaching to the treatment of abdominal bloating, clinicians should consider a heterogeneous condition produced by a combination of various mechanisms. Currently, there is no treatment which has indisputably proven to be effective for bloating. Treatment strategy for bloating may include pharmacologic approach, dietary modification, and psychological therapy. Taken together, $5-\mathrm{HT}_{4}$ agonists, antibiotics such as rifaximin, some probiotics, and also novel agents, lubiprostone and linaclotide are substantiated to be effective in some degree in the treatment of bloating. Dietary intervention with low FODMAP is also newly qualified treatment option. Though the evidence is weak, antifoaming agents and antidepressants could be consid- 


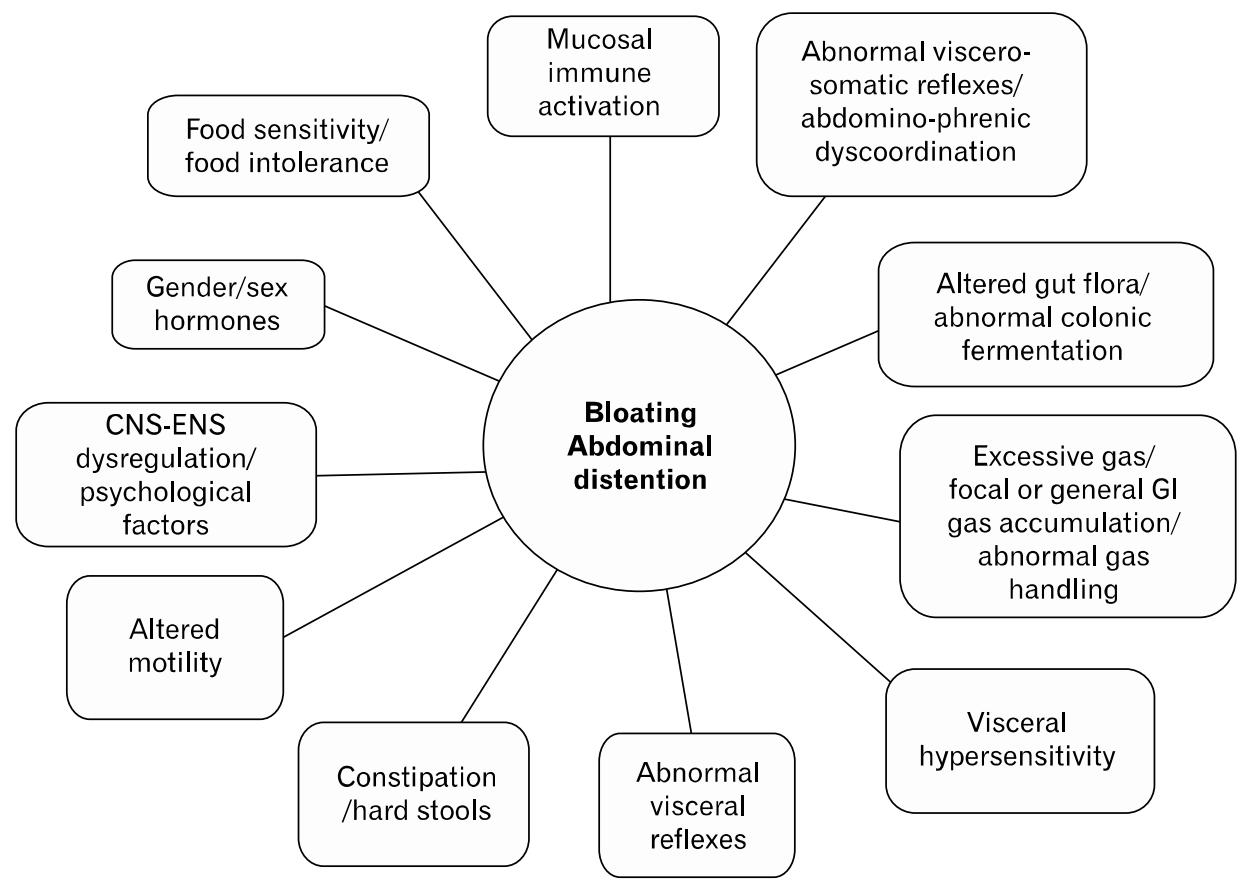

Figure 2. Potential mechanisms behind bloating and visible distension in functional gastrointestinal disorders. Modified from Simrén. ${ }^{168} \mathrm{CNS}$, central nervous system; ENS, enteric nervous system; GI, gastrointestinal. ered in some patients. Of course a careful history and physical examination should be the first step and reassurance and education are likewise important.

Though the whole mechanism and treatment strategies are yet to be fully elucidated, this article proposes a framework for assessing and managing the patients with bloating.

\section{References}

1. Bradette M, Delvaux M, Staumont G, Fioramonti J, Bueno L, Frexinos J. Evaluation of colonic sensory thresholds in IBS patients using a barostat. Definition of optimal conditions and comparison with healthy subjects. Dig Dis Sci 1994;39:449-457.

2. Issa B, Wafaei NA, Whorwell PJ. Abdominal bloating and distension: what is the role of the microbiota. Dig Dis Sci 2012;57:4-8.

3. Accarino A, Perez F, Azpiroz F, Quiroga S, Malagelada JR. Intestinal gas and bloating: effect of prokinetic stimulation. Am J Gastroenterol 2008;103:2036-2042.

4. Accarino A, Perez F, Azpiroz F, Quiroga S, Malagelada JR. Abdominal distention results from caudo-ventral redistribution of contents. Gastroenterology 2009;136:1544-1551.

5. Zar S, Benson MJ, Kumar D. Review article: bloating in functional bowel disorders. Aliment Pharmacol Ther 2002;16:1867-1876.

6. Houghton LA, Whorwell PJ. Towards a better understanding of abdominal bloating and distension in functional gastrointestinal disorders. Neurogastroenterol Motil 2005;17:500-511.

7. Azpiroz F, Malagelada JR. Abdominal bloating. Gastroenterology 2005;129:1060-1078.

8. Agrawal A, Whorwell PJ. Review article: abdominal bloating and distension in functional gastrointestinal disorders-epidemiology and exploration of possible mechanisms. Aliment Pharmacol Ther 2008;27:2-10.

9. Schmulson M, Chang L. Review article: the treatment of functional abdominal bloating and distension. Aliment Pharmacol Ther 2011;33:1071-1086

10. Lacy BE, Gabbard SL, Crowell MD. Pathophysiology, evaluation, and treatment of bloating: hope, hype, or hot air? Gastroenterol Hepatol (NY) 2011;7:729-739.

11. Fernández-Bañares F, Rosinach M, Esteve M, Forné M, Espinós JC, Maria Viver J. Sugar malabsorption in functional abdominal bloating: a pilot study on the long-term effect of dietary treatment. Clin Nutr 2006;25:824-831.

12. Azpiroz F, Levitt M. Intestinal Gas. In: Feldman M, Friedman LS, Brand LJ, eds. Sleisenger and Fordtran's. Gastrointestinal and liver disease: pathophysiology, diagnosis, management. Philadelphia: Saunders 2010:233-240.

13. Páramo Hernández DB. Bloating and abdominal distention: Just gas? A look in the direction of physiology. Rev Col Gastroenterol 2011;26:269-272.

14. Houghton LA, Lea R, Agrawal A, Reilly B, Whorwell PJ. Relationship of abdominal bloating to distention in irritable bowel syndrome and effect of bowel habit. Gastroenterology 2006;131: 1003-1010.

15. Agrawal A, Houghton LA, Reilly B, Morris J, Whorwell PJ. Bloating and distension in irritable bowel syndrome: the role of gastrointestinal transit. Am J Gastroenterol 2009;104:1998-2004.

16. Jiang X, Locke GR 3rd, Choung RS, Zinsmeister AR, Schleck $\mathrm{CD}$, Talley NJ. Prevalence and risk factors for abdominal bloating and visible distention: a population-based study. Gut 2008;57: 756-763.

17. Thompson WG, Longstreth GF, Drossman DA, Heaton KW, Irvine EJ, Müller-Lissner SA. Functional bowel disorders and 
functional abdominal pain. Gut 1999;45(suppl 2):II43-II47.

18. Drossman DA, Corazziari E, Tally NJ, Thompson W, Whitehead W. Rome II. The functional gastrointestinal disorders. Diagnosis, pathophysiology and treatment: amultinational consensus, 2nd ed. McLean, VA: Degnon Associates Inc 2000.

19. Longstreth GF, Thompson WG, Chey WD, Houghton LA, Mearin F, Spiller RC. Functional bowel disorders. Gastroenterology 2006;130:1480-1491.

20. Alvarez WC. Hysterical type of nongaseous abdominal bloating. Arch Intern Med (Chic) 1949;84:217-245.

21. Ringel Y, Williams RE, Kalilani L, Cook SF. Prevalence,characteristics, and impact of bloating symptoms in patients with irritable bowel syndrome. clin Gastroenterol Hepatol 2009;7:68-72.

22. Sandler R, Stewart W, Liberman J, Ricci J, Zorich N. Abdominal pain, bloating, and diarrheain the united states. Dig Dis Sci 2000;45:1166-1171.

23. Ho KY, Kang JY, Seow A. Prevalence of gastrointestinal symptoms in a multiracial Asian population, with particular reference to reflux-type symptoms. Am J Gastroenterol 1998;93:1816-1822.

24. Heitkemper MM, Cain KC, Jarrett ME, Burr RL, Hertig V, Bond EF. Symptoms across the menstrual cycle in women with irritable bowel syndrome. Am J Gastroenterol 2003;98:420-430.

25. Huerta-Franco MR, Malacara JM. Association of physical and emotional symptoms with the menstrual cycle and life-style. J Reprod Med 1993;38:448-454.

26. Delgado-Aros S, Locke GR 3rd, Camilleri M, et al. Obesity is associated with increased risk of gastrointestinal symptoms: a population-based study. Am J Gastroenterol 2004;99:1801-1806.

27. Talley NJ, Quan C, Jones MP, Horowitz M. Association of upper and lower gastrointestinal tract symptoms with body mass index in an Australian cohort. Neurogastroenterol Motil 2004;16:413-419.

28. Maxton DG, Morris JA, Whorwell PJ. Ranking of symptoms by patients with the irritable bowel syndrome. BMJ 1989;299:1138.

29. Chang L, Lee OY, Naliboff B, Schmulson M, Mayer EA. Sensation of bloating and visible abdominal distension in patients with irritable bowel syndrome. Am J Gastroenterol 2001;96: 3341-3347.

30. Houghton LA. Bloating in constipation: relevance of intraluminal gas handling. Best Pract Res Clin Gastroenterol 2011;25:141-150.

31. Talley NJ, Dennis EH, Schettler-Duncan VA, Lacy BE, Olden KW, Crowell MD. Overlapping upper and lower gastrointestinal symptoms in irritable bowel syndrome patients with constipation or diarrhea. Am J Gastroenterol 2003;98:2454-2459.

32. Balsari A, Ceccarelli A, Dubini F, Fesce E, Poli G. The fecal microbial population in the irritable bowel syndrome. Microbiologica 1982;5:185-194.

33. Malinen E, Rinttilä T, Kajander K, et al. Analysis of the fecal microbiota of irritable bowel syndrome patients and healthy controls with real-time PCR. Am J Gastroenterol 2005;100:373-382.

34. Lee BJ, Bak YT. Irritable bowel syndrome, gut microbiota and probiotics. J Neurogastroenterol Motil 2011;17:252-266.

35. Parkes GC, Brostoff J, Whelan K, Sanderson JD. Gastrointestinal microbiota in irritable bowel syndrome: their role in its pathogenesis and treatment. Am J Gastroenterol 2008;103:1557-1567.

36. Kassinen A, Krogius-Kurikka L, Mäkivuokko H, et al. The fecal microbiota of irritable bowel syndrome patients differs significantly from that of healthy subjects. Gastroenterology 2007;133:24-33.

37. Ponnusamy K, Choi JN, Kim J, Lee SY, Lee CH. Microbial community and metabolomic comparison of irritable bowel syndrome faeces. J Med Microbiol 2011;60(Pt 6):817-827.

38. Tana C, Umesaki Y, Imaoka A, Handa T, Kanazawa M, Fukudo $\mathrm{S}$. Altered profiles of intestinal microbiota and organic acids may be the origin of symptoms in irritable bowel syndrome. Neurogastroenterol Motil 2010;22:512-519, e114-e115.

39. King TS, Elia M, Hunter JO. Abnormal colonic fermentation in irritable bowel syndrome. Lancet 1998;352:1187-1189.

40. Collins SM, Denou E, Verdu EF, Bercik P. The putative role of the intestinal microbiota in the irritable bowel syndrome. Dig Liver Dis 2009; 41:850-853.

41. Nobaek S, Johansson M-L, Molin G, Ahrné S, Jeppsson B. Alteration of intestinal microflora is associated with reduction in abdominal bloating and pain in patients with irritable bowel syndrome. Am J Gastroenterol 2000;95:1231-1238.

42. Kajs TM, Fitzgerald JA, Buckner RY, et al. Influence of a methanogenic flora on the breath $\mathrm{H} 2$ and symptom response to ingestion of sorbitol or oat fiber. Am J Gastroenterol 1997;92:89-94.

43. Vernia P, Camillo MD, Marinaro V, Caprilli R. Effect of predominant methanogenic flora on the outcome of lactose breath test in irritable bowel syndrome patients. Eur J Clin Nutr 2003;57:11161119.

44. Pimentel M, Park S, Mirocha J, Kane SV, Kong Y. The effect of a nonabsorbed oral antibiotic (rifaximin) on the symptoms of the irritable bowel syndrome: a randomized trial. Ann Intern Med 2006; 145:557-563.

45. Sharara AI, Aoun E, Abdul-Baki H, Mounzer R, Sidani S, ElHajj I. A randomized double-blind placebo-controlled trial of rifaximin in patients with abdominal bloating and flatulence. Am J Gastroenterol 2006;101:326-333.

46. Di Stefano M, Strocchi A, Malservisi S, Veneto G, Ferrieri A, Corazza GR. Non-absorbable antibiotics for managing intestinal gas production and gas-related symptoms. Aliment Pharmacol Ther 2000;14:1001-1008.

47. Walters B, Vanner SJ. Detection of bacterial overgrowth in IBS using the lactulose $\mathrm{H}_{2}$ breath test: comparison with ${ }^{14} \mathrm{C}$-D-xylose and healthy controls. Am J Gastroenterol 2005;100:1566-1570.

48. Posserud I, Stotzer PO, Björnsson ES, Abrahamsson H, Simrén M. Small intestinal bacterial overgrowth in patients with irritable bowel syndrome. Gut 2007;56:802-808.

49. Riordan SM, McIver CJ, Duncombe VM, Thomas MC, Nagree A, Bolin TD. Small intestinal bacterial overgrowth and the irritable bowel syndrome. Am J Gastroenterol 2001;96:2506-2508.

50. Haderstorfer B, Psycholgin D, Whitehead WE, Schuster MM. Intestinal gas production from bacterial fermentation of undigested carbohydrate in irritable bowel syndrome. Am J Gastroenterol 1989;84:375-378.

51. Grace E, Shaw C, Whelan K, Andreyev HJ. Review article: small intestinal bacterial overgrowth-prevalence, clinical features, current and developing diagnostic tests, and treatment. Aliment Pharmacol Ther 2013;38:674-688.

52. Chami TN, Schuster MM, Bohlman ME, Pulliam TJ, Kamal N, Whitehead WE. A simple radiologic method to estimate the quantity of bowel gas. Am J Gastroenterol 1991;86:599-602. 
53. Koide A, Yamaguchi T, Odaka T, et al. Quantitative analysis of bowel gas using plain abdominal radiograph in patients with irritable bowel syndrome. Am J Gastroenterol 2000;95:1735-1741.

54. Lasser RB, Bond JH, Levitt MD. The role of intestinal gas in functional abdominal pain. N Engl J Med 1975;293:524-526.

55. Drossman DA, Camilleri M, Mayer EA, Whitehead WE. AGA technical review on irritable bowel syndrome. Gastroenterology 2002;123:2108-2131.

56. Cann PA, Read NW, Brown C, Hobson N, Holdsworth CD. Irritable bowel syndrome: relationship of disorders in the transit of a single solid meal to symptom patterns. Gut 1983;24:405-411.

57. Kellow JE, Phillips SF. Altered small bowel motility in irritable bowel syndrome is correlated with symptoms. Gastroenterology 1987;92:1885-1893.

58. Lee OY. Asian motility studies in irritable bowel syndrome. J Neurogastroenterol Motil 2010;16:120-130.

59. Tornblom H, Van Oudenhove L, Sadik R, Abrahamsson H, Tack J, Simrén M. Colonic transit time and IBS symptoms: what's the link? Am J Gastroenterol 2012;107:754-760.

60. Serra J, Azpiroz F, Malagelada JR. Impaired transit and tolerance of intestinal gas in the irritable bowel syndrome. Gut 2001;48: 14-19.

61. Salvioli B, Serra J, Azpiroz F, et al. Origin of gas retention and symptoms in patients with bloating. Gastroenterology 2005;128: 574-579.

62. Harder H, Serra J, Azpiroz F, Passos MC, Aguadé S, Malagelada JR. Intestinal gas distribution determines abdominal symptoms. Gut 2003;52:1708-1713.

63. Serra J, Azpiroz F, Malagelada JR. Mechanisms of intestinal gas retention in humans: impaired propulsion versus obstructed evacuation. Am J Physiol Gastrointest Liver Physiol 2001;281: G138-G143.

64. Shim L, Prott G, Hansen RD, Simmons LE, Kellow JE, Malcolm A. Prolonged balloon expulsion is predictive of abdominal distension in bloating. Am J Gastroenterol 2010;105:883-887.

65. Sullivan SN. A prospective study of unexplained visible abdominal bloating. N Z Med J 1994;107:428-430.

66. McManis PG, Newall D, Talley NJ. Abdominal wall muscle activity in irritable bowel syndrome with bloating. Am J Gastroenterol 2001;96:1139-1142.

67. Maxton DG, Martin DF, Whorwell PJ, Godfrey M. Abdominal distension in female patients with irritable bowel syndrome: exploration of possible mechanisms. Gut 1991;32:662-664.

68. Tremolaterra F, Villoria A, Azpiroz F, Serra J, Aguadé S, Malagelada JR. Impaired viscerosomatic reflexes and abdominal-wall dystony associated with bloating. Gastroenterology 2006; 130:1062-1068.

69. Villoria A, Azpiroz F, Burri E, Cisternas D, Soldevilla A, Malagelada JR. Abdomino-phrenic dyssynergia in patients with abdominal bloating and distension. Am J Gastroenterol 2011;106: 815-819.

70. Villoria A, Azpiroz F, Soldevilla A, Perez F, Malagelada JR. Abdominal accommodation: a coordinated adaptation of the abdominal wall to its content. Am J Gastroenterol 2008;103: 2807-2815.

71. Bouin M, Plourde V, Boivin M, et al. Rectal distention testing in patients with irritable bowel syndrome: sensitivity, specificity, and predictive values of pain sensory thresholds. Gastroenterology 2002;122:1771-1777.

72. Kellow JE, Eckersley CM, Jones MP. Enhanced perception of physiological intestinal motility in the irritable bowel syndrome. Gastroenterology 1991;101:1621-1627.

73. Mertz H, Naliboff B, Munakata J, Niazi N, Mayer EA. Altered rectal perception is a biological marker of patients with irritable bowel syndrome. Gastroenterology 1995;109:40-52.

74. Agrawal A, Houghton LA, Lea R, Morris J, Reilly B, Whorwell PJ. Bloating and distention in irritable bowel syndrome: the role of visceral sensation. Gastroenterology 2008;134:1882-1889.

75. Park DI, Rhee PL, Kim YH, et al. Role of autonomic dysfunction in patients with functional dyspepsia. Dig Liver Dis 2001;33: 464-471.

76. Iovino P, Azpiroz F, Domingo E, Malagelada JR. The sympathetic nervous system modulates perception and reflex responses to gut distention in humans. Gastroenterology 1995;108:680-686.

77. Azpiroz F, Bouin M, Camilleri M, et al. Mechanisms of hypersensitivity in IBS and functional disorders. Neurogastroenterol Motil 2007;19(1 suppl):62-88

78. Accarino AM, Azpiroz F, Malagelada JR. Attention and distraction: effects on gut perception. Gastroenterology 1997;113: 415-422.

79. Houghton LA, Lea R, Jackson N, Whorwell PJ. The menstrual cycle affects rectal sensitivity in patients with irritable bowel syndrome but not healthy volunteers. Gut 2002;50:471-474.

80. Francis CY, Whorwell PJ. Bran and irritable bowel syndrome: time for reappraisal. Lancet 1994;344:39-40.

81. Friedman G. Diet and the irritable bowel syndrome. Gastroenterol Clin North Am 1991;20:313-324.

82. Böhmer CJ, Tuynman HA. The clinical relevance of lactose malabsorption in irritable bowel syndrome. Eur J Gastroenterol Hepatol 1996;8:1013-1016.

83. Dapoigny M, Stockbrügger RW, Azpiroz F, et al. Role of alimentation in irritable bowel syndrome. Digestion 2003;67:225-233.

84. Fernández-Bañares F, Esteve-Pardo M, de Leon R, et al. Sugar malabsorption in functional bowel disease: clinical implications. Am J Gastroenterol 1993;88:2044-2050.

85. Roberfroid MB, Van Loo JA, Gibson GR. The bifidogenic nature of chicory inulin and its hydrolysis products. J Nutr 1998;128: 11-19.

86. O'Leary C, Quigley EM. Small bowel bacterial overgrowth, celiac disease, and IBS: what are the real associations? Am J Gastroenterol 2003;98:720-722.

87. Tursi A, Brandimarte G, Giorgetti G. High prevalence of small intestinal bacterial overgrowth in celiac patients with persistence of gastrointestinal symptoms after gluten withdrawal. Am J Gastroenterol 2003;98:839-843

88. Barrett JS, Gearry RB, Muir JG, et al. Dietary poorly absorbed, short-chain carbohydrates increase delivery of water and fermentable substrates to the proximal colon. Aliment Pharmacol Ther 2010;31:874-882.

89. Ong DK, Mitchell SB, Barrett JS, et al. Manipulation of dietary short chain carbohydrates alters the pattern of gas production and genesis of symptoms in irritable bowel syndrome. J Gastroenterol 
Hepatol 2010;25:1366-1373.

90. Levitt MD, Furne J, Olsson S. The relation of passage of gas an abdominal bloating to colonic gas production. Ann Intern Med 1996;124:422-424.

91. Hebden JM, Blackshaw E, D’Amato M, Perkins AC, Spiller RC. Abnormalities of GI transit in bloated irritable bowel syndrome: effect of bran on transit and symptoms. Am J Gastroenterol 2002; 97:2315-2320.

92. Schmulson M, Chang L, Naliboff B, Lee OY, Mayer EA. Correlation of symptom criteria with perception thresholds during rectosigmoid distension in irritable bowel syndrome patients. Am J Gastroenterol 2000;95:152-156.

93. Su AM, Shih W, Presson AP, Chang L. Characterization of symptoms in irritable bowel syndrome with mixed bowel habit pattern. Neurogastroenterol Motil 2013 Published Online First: 29 Aug 2013. doi: $10.1111 / \mathrm{nmo.} 12220$.

94. Ringel Y, Williams RE, Kalilani L, Cook SF. Prevalence, characteristics, and impact of bloating symptoms in patients with irritable bowel syndrome. Clin Gastroenterol Hepatol 2009;7:68-72.

95. Park HJ, Jarrett M, Cain K, Heitkemper M. Psychological distress and GI symptoms are related to severity of bloating in women with irritable bowel syndrome. Res Nurs Health 2008;31:98-107.

96. Song JY, Merskey H, Sullivan S, Noh S. Anxiety and depression in patients with abdominal bloating. Can J Psychiatry 1993;38:475479.

97. Johnsen R, Jacobsen BK, Førde OH. Associations between symptoms of irritable colon and psychological and social conditions and lifestyle. Br Med J (Clin Res Ed) 1986;292:1633-1635.

98. Walker EA, Katon WJ, Jemelka RP, Roy-Bryne PP. Comorbidity of gastrointestinal complaints, depression, and anxiety in the Epidemiologic Catchment Area (ECA) Study. Am J Med 1992; 92:26S-30S.

99. Heitkemper MM, Cain KC, Jarrett ME, Burr RL, Crowell MD, Woods NF. Relationship of bloating to other GI and menstrual symptoms in women with irritable bowel syndrome. Dig Dis Sci 2004;49:88-95.

100. Smith RC, Greenbaum DS, Vancouver JB, et al. Gender differences in manning criteria in the irritable bowel syndrome. Gastroenterology 1991;100:591-595.

101. Schmulson M, Lee OY, Chang L, Naliboff B, Mayer EA. Symptom differences in moderate to severe IBS patients based on predominant bowel habit. Am J Gastroenterol 1999;94:2929-2935.

102. Anbardan SJ, Daryani NE, Fereshtehnejad SM, Taba Taba Vakili S, Keramati MR, Ajdarkosh H. Gender role in irritable bowel syndrome: A comparison of irritable bowel syndrome module (Rome III) between male and female patients. J Neurogastroenterol Motil 2012;18:70-77.

103. Altman G, Cain KC, Motzer S, Jarrett M, Burr R, Heitkemper M. Increased symptoms in female IBS patients with dysmenorrhea and PMS. Gastroenterol Nurs 2006;29:4-11.

104. Spiller RC. Role of infection in irritable bowel syndrome. J Gastroenterol 2007;42(suppl 17):41-47.

105. Pimentel M, Lezcano S. Irritable bowel syndrome: bacterial overgrowth-what's known and what to do. Curr Treat Options Gastroenterol 2007;10:328-337.

106. Yu D, Cheeseman F, Vanner S. Combined oro-caecal scintigraphy and lactulose hydrogen breath testing demonstrate that breath testing detects oro-caecal transit, not small intestinal bacterial overgrowth in patients with IBS. Gut 2011;60:334-340.

107. Corazza GR, Ventrucci M, Strocchi A, et al. Treatment of small intestine bacterial overgrowth with rifaximin, a non-absorbable rifamycin. J Int Med Res 1988;16:312-316.

108. Scarpellini E, Gabrielli M, Lauritano CE, et al. High dosage rifaximin for the treatment of small intestinal bacterial overgrowth Aliment Pharmacol Ther 2007;25:781-786.

109. Pimentel M, Lembo A, Chey WD, et al. Rifaximin therapy for patients with irritable bowel syndrome without constipation. N Engl J Med 2011;364:22-32.

110. Pimentel M, Chow EJ, Lin HC. Normalization of lactulose breath testing correlates with symptom improvement in irritable bowel syndrome. a double-blind, randomized, placebo-controlled study. Am J Gastroenterol 2003;98:412-419.

111. Peralta S, Cottone C, Doveri T, Almasio PL, Craxi A. Small intestine bacterial overgrowth and irritable bowel syndrome-related symptoms: experience with Rifaximin. World J Gastroenterol 2009; 15:2628-2631.

112. Jolley J. High-dose rifaximin treatment alleviates global symptoms of irritable bowel syndrome. Clin Exp Gastroenterol 2011;4:43-48.

113. Yang J, Lee HR, Low K, Chatterjee S, Pimentel M. Rifaximin versus other antibiotics in the primary treatment and retreatment of bacterial overgrowth in IBS. Dig Dis Sci 2008;53:169-174.

114. O'Mahony L, McCarthy J, Kelly P, et al. Lactobacillus and bifidobacterium in irritable bowel syndrome: symptom responses and relationship to cytokine profiles. Gastroenterology 2005;128:541-551.

115. Whorwell PJ, Altringer L, Morel J, et al. Efficacy of an encapsulated probiotic Bifidobacterium infantis 35624 in women with irritable bowel syndrome. Am J Gastroenterol 2006;101:1581-1590.

116. Guglielmetti S, Mora D, Gschwender M, Popp K. Randomised clinical trial: Bifidobacterium bifidum MIMBb75 significantly alleviates irritable bowel syndrome and improves quality of life - a double-blind, placebo-controlled study. Aliment Pharmacol Ther 2011;33:1123-1132.

117. Ducrotté $P$, Sawant $P$, Jayanthi V. Clinical trial: Lactobacillus plantarum 299v (DSM 9843) improves symptoms of irritable bowel syndrome. World J Gastroenterol 2012;18:4012-4018.

118. Yoon JS, Sohn W, Lee OY, et al. Effect of multi-species probiotics on irritable bowel syndrome: a randomized, double-blind, placebo-controlled trial. J Gastroenterol Hepatol Published Online First: 5 Jul 2013. doi: 10.1111/jgh.12322.

119. Hungin AP, Mulligan C, Pot B, et al. Systematic review: probiotics in the management of lower gastrointestinal symptoms in clinical practice-an evidence-based international guide. Aliment Pharmacol Ther Published Online First: 27 Aug 2013. doi: 10.1111/apt.12460.

120. Kim HJ, Vazquez Roque MI, Camilleri M, et al. A randomized controlled trial of a probiotic combination VSL\# 3 and placebo in irritable bowel syndrome with bloating. Neurogastroenterol Motil 2005;17:687-696.

121. Choi CH, Jo SY, Park HJ, Chang SK, Byeon JS, Myung SJ. A randomized, double-blind, placebo-controlled multicenter trial of Saccharomyces boulardii in irritable bowel syndrome: effect on quality of life. J Clin Gastroenterol 2011;45:679-683.

122. Ki Cha B, Mun Jung S, Hwan Choi C, et al. The effect of a multi- 
species probiotic mixture on the symptoms and fecal microbiota in diarrhea-dominant irritable bowel syndrome: a randomized, double-blind, placebo-controlled trial. J Clin Gastroenterol 2012;46: 220-227.

123. O'Sullivan MA, O'Morain CA. Bacterial supplementation in the irritable bowel syndrome. A randomised double-blind placebo-controlled crossover study. Dig Liver Dis 2000;32:294-301.

124. Niv E, Naftali T, Hallak R, Vaisman N. The efficacy of Lactobacillus reuteri ATCC 55730 in the treatment of patients with irritable bowel syndrome - a double blind, placebo-controlled, randomized study. Clin Nutr 2005;24:925-931.

125. Champion MC, MacCannell KL, Thomson AB, et al. A double-blind randomized study of cisapride in the treatment of nonulcer dyspepsia. The Canadian Cisapride Nud Study Group. Can J Gastroenterol 1997;11:127-134.

126. Chen JD, Ke MY, Lin XM, Wang Z, Zhang M. Cisapride provides symptomatic relief in functional dyspepsia associated with gastric myoelectrical abnormality. Aliment Pharmacol Ther 2000;14: 1041-1047.

127. Mearin F, Rodrigo L, Pérez-Mota A, et al. Levosulpiride and cisapride in the treatment of dysmotility-like functional dyspepsia: a randomized, double-masked trial. Clin Gastroenterol Hepatol 2004;2:301-308.

128. Tack J, Masclee A, Heading R, et al. A dose-ranging, placebo-controlled, pilot trial of acotiamide in patients with functional dyspepsia. Neurogastroenterol Motil 2009;21:272-280.

129. Muller-Lissner SA, Fumagalli I, Bardhan KD, et al. Tegaserod, a $5-\mathrm{HT}_{4}$ receptor partial agonist, relieves symptoms in irritable bowel syndrome patients with abdominal pain, bloating and constipation. Aliment Pharmacol Ther 2001;15:1655-1666.

130. Novick J, Miner P, Krause R, et al. A randomized, double-blind, placebo-controlled trial of tegaserod in female patients suffering from irritable bowel syndrome with constipation. Aliment Pharmacol Ther 2002;16:1877-1888.

131. Kellow J, Lee OY, Chang FY, et al. An Asia-Pacific, double blind, placebo controlled, randomised study to evaluate the efficacy, safety, and tolerability of tegaserod in patients with irritable bowel syndrome. Gut 2003;52:671-676.

132. Tack J, Müller-Lissner S, Bytzer P, et al. A randomised controlled trial assessing the efficacy and safety of repeated tegaserod therapy in women with irritable bowel syndrome with constipation. Gut 2005;54:1707-1713.

133. Caldarella MP, Serra J, Azpiroz F, Malagelada JR. Prokinetic effects in patients with intestinal gas retention. Gastroenterology 2002;122:1748-1755.

134. Schütze K, Brandstatter G, Dragosics B, Judmaier G, Hentschel E. Double-blind study of the effect of cisapride on constipation and abdominal discomfort as components of the irritable bowel syndrome. Aliment Pharmacol Ther 1997;11:387-394.

135. Cann PA, Read NW, Holdsworth CD. Oral domperidone: double blind comparison with placebo in irritable bowel syndrome. Gut 1983;24:1135-1140.

136. McKee DP, Quigley EM. Intestinal motility in irritable bowel syndrome: is IBS a motility disorder? Part 1. Definition of IBS and colonic motility. Dig Dis Sci 1993;38:1761-1772.

137. Dumitrascu DL, Stănculete M. The effect of trimebutine on the psychosocial adjustment to illness in the irritable bowel syndrome. Rom J Intern Med 2006;44:273-280.

138. Ford AC, Talley NJ, Spiegel BM, et al. Effect of fibre, antispasmodics, and peppermint oil in the treatment of irritable bowel syndrome: systematic review and meta-analysis. BMJ 2008;337: a2313.

139. Poynard T, Regimbeau C, Benhamou Y. Meta-analysis of smooth muscle relaxants in the treatment of irritable bowel syndrome. Aliment Pharmacol Ther 2001;15:355-361.

140. Clave P, Acalovschi M, Triantafillidis JK, et al. Randomised clinical trial: otilonium bromide improves frequency of abdominal pain, severity of distention and time to relapse in patients with irritable bowel syndrome. Aliment Pharmacol Ther 2011;34:432-442.

141. Battaglia G, Morselli-Labate AM, Camarri E, et al. Otilonium bromide in irritable bowel syndrome: a double-blind, placebo-controlled, 15-week study. Aliment Pharmacol Ther 1998;12:10031010 .

142. Luttecke K. A three-part controlled study of trimebutine in the treatment of irritable colon syndrome. Curr Med Res Opin 1980; 6:437-443.

143. Glende M, Morselli-Labate AM, Battaglia G, Evangelista S. Extended analysis of a double-blind, placebo-controlled, 15-week study with otilonium bromide in irritable bowel syndrome. Eur J Gastroenterol Hepatol 2002;14:1331-1338.

144. Liu JH, Chen GH, Yeh HZ, Huang CK, Poon SK. Enteric-coated peppermint-oil capsules in the treatment of irritable bowel syndrome: a prospective, randomized trial. J Gastroenterol 1997;32: 765-768.

145. Cappello G, Spezzaferro M, Grossi L, Manzoli L, Marzio L. Peppermint oil (Mintoil) in the treatment of irritable bowel syndrome: a prospective double blind placebo-controlled randomized trial. Dig Liver Dis 2007;39:530-536.

146. Darvish-Damavandi M, Nikfar S, Abdollahi M. A systematic review of efficacy and tolerability of mebeverine in irritable bowel syndrome. World J Gastroenterol 2010;16:547-553.

147. Choi YK, Kraft N, Zimmerman B, Jackson M, Rao SS. Fructose intolerance in IBS and utility of fructose-restricted diet. J Clin Gastroenterol 2008;42:233-238.

148. Barrett JS, GIbson PR. Clinical ramifications of malabsorption of fructose and other short-chain carbohydrates. Pract Gastroenterol 2007;31:51-65.

149. Shepherd SJ, Parker FC, Muir JG, Gibson PR. Dietary triggers of abdominal symptoms in patients with irritable bowel syndrome: randomized placebo-controlled evidence. Clin Gastroenterol Hepatol 2008;6:765-771.

150. Gibson PR, Shepherd SJ. Personal view: food for thought-western lifestyle and susceptibility to Crohn's disease. The FODMAP hypothesis. Aliment Pharmacol Ther 2005;21:1399-1409.

151. de Roest RH, Dobbs BR, Chapman BA, et al. The low FODMAP diet improves gastrointestinal symptoms in patients with irritable bowel syndrome: a prospective study. Int J Clin Pract 2013;67: 895-903.

152. Rider JA. Experience with the use of a defoaming agent in the treatment of gastrointestinal gas. Ann N Y Acad Sci 1968;150:170-177.

153. Bernstein JE, Kasich AM. A double-blind trial of simethicone in functional disease of the upper gastrointestinal tract. J Clin 
Pharmacol 1974;14:617-623.

154. Holtmann G, Gschossmann J, Mayr P, Talley NJ. A randomized placebo-controlled trial of simethicone and cisapride for the treatment of patients with functional dyspepsia. Aliment Pharmacol Ther 2002;16:1641-1648.

155. Lecuyer M, Cousin T, Monnot MN, Coffin B. Efficacy of an activated charcoal-simethicone combination in dyspeptic syndrome: results of a randomized prospective study in general practice. Gastroenterol Clin Biol 2009;33:478-484.

156. Johanson JF, Ueno R. Lubiprostone, a locally acting chloride channel activator, in adult patients with chronic constipation: a double-blind, placebo-controlled, dose - ranging study to evaluate efficacy and safety. Aliment Pharmacol Ther 2007;25:1351-1361.

157. Drossman DA, Chey WD, Johanson JF, et al. Clinical trial: lubiprostone in patients with constipation-associated irritable bowel syndrome-results of two randomized, placebo-controlled studies. Aliment Pharmacol Ther 2009;29:329-341.

158. Quigley EM, Tack J, Chey WD, et al. Randomised clinical trials: linaclotide phase 3 studies in IBS-C - a prespecified further analysis based on European Medicines Agency-specified endpoints. Aliment Pharmacol Ther 2013;37:49-61.

159. Lembo AJ, Schneier HA, Shiff SJ, et al. Two randomized trials of linaclotide for chronic constipation. N Engl J Med 2011;365: 527-536.

160. Kuiken SD, Tytgat GN, Boeckxstaens GE. The selective serotonin reuptake inhibitor fluoxetine does not change rectal sensitivity and symptoms in patients with irritable bowel syndrome: a double blind, randomized, placebo-controlled study. Clin Gastroenterol Hepatol 2003;1:219-228.

161. Tabas G, Beaves M, Wang J, Friday P, Mardini H, Arnold G. Paroxetine to treat irritable bowel syndrome not responding to high-fiber diet: a double-blind, placebo-controlled trial. Am J Gastroenterol 2004;99:914-920.

162. Tack J, Broekaert D, Fischler B, Van Oudenhove L, Gevers AM, Janssens J. A controlled crossover study of the selective serotonin reuptake inhibitor citalopram in irritable bowel syndrome. Gut 2006;55:1095-1103.

163. Corazziari E. Role of opioid ligands in the irritable bowel syndrome. Can J Gastroenterol 1999;13(suppl A):71A-75A.

164. Fraitag B, Homerin M, Hecketsweiler P. Double-blind dose-response multicenter comparison of fedotozine and placebo in treatment of nonulcer dyspepsia. Dig Dis Sci 1994;39:1072-1077.

165. Mangel A, Bornstein J, Hamm L, et al. Clinical trial: asimadoline in the treatment of patients with irritable bowel syndrome. Aliment Pharmacol Ther 2008;28:239-249.

166. Hawkes ND, Rhodes J, Evans BK, Rhodes P, Hawthorne AB, Thomas GA. Naloxone treatment for irritable bowel syndrome - a randomized controlled trial with an oral formulation. Aliment Pharmacol Ther 2002;16:1649-1654.

167. Camilleri M. Current and future pharmacological treatments for diarrhea-predominant irritable bowel syndrome. Expert Opin Pharmacother 2013;14:1151-1160.

168. Simrén M. Bloating and abdominal distention: not so poorly understood anymore! Gastroenterology 2009;136:1487-1490.

169. Chey WD, Paré P, Viegas A, Ligozio G, Shetzline MA. Tegaserod for female patients suffering from IBS with mixed bowel habits or constipation: a randomized controlled trial. Am J Gastroenterol 2008;103:1217-1225.

170. George AM, Meyers NL, Hickling RI. Clinical trial: renzapride therapy for constipation-predominant irritable bowel syndrome multicentre, randomized, placebo-controlled, double-blind study in primary healthcare setting. Aliment Pharmacol Ther 2008;27: 830-837.

171. Dobrilla G, Imbimbo BP, Piazzi L, Bensi G. Longterm treatment of irritable bowel syndrome with cimetropium bromide: a double blind placebo controlled clinical trial. Gut 1990;31:355-358.

172. Mitchell SA, Mee AS, Smith GD, Palmer KR, Chapman RW. Alverine citrate fails to relieve the symptoms of irritable bowel syndrome: results of a double-blind, randomized, placebo-controlled trial. Aliment Pharmacol Ther 2002;16:1187-1195.

173. Chang FY, Lu CL, Luo JC, Chen TS, Chen MJ, Chang HJ. The evaluation of otilonium bromide treatment in asian patients with irritable bowel syndrome. J Neurogastroenterol Motil 2011;17: 402-410

174. Wittmann T, Paradowski L, Ducrotté P, Bueno L, Andro Delestrain MC. Clinical trial: the efficacy of alverine citrate/simeticone combination on abdominal pain/discomfort in irritable bowel syndrome - a randomized, double-blind, placebo-controlled study. Aliment Pharmacol Ther 2010;31:615-624.

175. Vahedi H, Merat S, Rashidioon A, Ghoddoosi A, Malekzadeh R. The effect of fluoxetine in patients with pain and constipation-predominant irritable bowel syndrome: a double-blind randomizedcontrolled study. Aliment Pharmacol Ther 2005;22:381-385.

176. Vahedi H, Merat S, Momtahen S, et al. Clinical trial: the effect of amitriptyline in patients with diarrhoea-predominant irritable bowel syndrome. Aliment Pharmacol Ther 2008;27:678-684.

177. Read NW, Abitbol JL, Bardhan KD, Whorwell PJ, Fraitag B. Efficacy and safety of the peripheral kappa agonist fedotozine versus placebo in the treatment of functional dyspepsia. Gut 1997;41: 664-668.

178. Szarka LA, Camilleri M, Burton D, et al. Efficacy of on-demand asimadoline, a peripheral kappa-opioid agonist, in females with irritable bowel syndrome. Clin Gastroenterol Hepatol 2007;5:12681275 . 